NBER WORKING PAPER SERIES

\title{
EARNINGS MANIPULATION AND MANAGERIAL INVESTMENT DECISIONS: EVIDENCE FROM SPONSORED PENSION PLANS
}

\author{
Daniel Bergstresser \\ Mihir A. Desai \\ Joshua Rauh \\ Working Paper 10543 \\ http://www.nber.org/papers/w10543 \\ NATIONAL BUREAU OF ECONOMIC RESEARCH \\ 1050 Massachusetts Avenue \\ Cambridge, MA 02138 \\ June 2004
}

The authors thank Shlomo Benartzi, David Cutler, David Hawkins, Caroline Hoxby, Dirk Jenter, André Perold, James Poterba, Andrei Shleifer, Jeremy Stein and various seminar participants for helpful comments. Conversations and email exchanges with Ron Gebhardtsbauer of the American Academy of Actuaries, James Marple of Watson Wyatt, and Jerrold Levy of Mercer Consulting were particularly helpful. The Division of Research at Harvard Business School provided generous financial support. The views expressed herein are those of the author(s) and not necessarily those of the National Bureau of Economic Research.

C2004 by Daniel Bergstresser, Mihir A. Desai, and Joshua Rauh. All rights reserved. Short sections of text, not to exceed two paragraphs, may be quoted without explicit permission provided that full credit, including (C) notice, is given to the source. 
Earnings Manipulation and Managerial Investment Decisions:

Evidence from Sponsored Pension Plans

Daniel Bergstresser, Mihir A. Desai, and Joshua Rauh

NBER Working Paper No. 10543

June 2004

JEL No. M41, M52, G23, G30, G11

\section{$\underline{\text { ABSTRACT }}$}

Managers appear to manipulate firm earnings when they characterize pension assets to capital markets and alter investment decisions to justify, and capitalize on, these manipulations. We construct a measure of the sensitivity of reported earnings to the assumed long-term rate of return on pension assets. Managers are more aggressive with assumed long-term rates of return when their assumptions have a greater impact on reported earnings. Managers also increase assumed rates of return as they prepare to acquire other firms and as they exercise stock options, further confirming the opportunistic nature of these increases. Decisions about assumed rates of return, in turn, influence asset allocation within pension plans. Instrumental variables results suggest that a 25 basis point increase in the assumed rate of return is associated with a $5 \%$ increase in equity allocation. Taken together, these results suggest that earnings manipulation arising from managerial motivations influences significant managerial investment decisions.

\author{
Daniel Bergstresser \\ Harvard Business School \\ Morgan 391 \\ Soldiers Field \\ Boston, MA 02163 \\ dbergstresser@hbs.edu
}

\author{
Mihir A. Desai \\ Harvard Business School \\ Morgan 363 \\ Soldiers Field \\ Boston, MA 02163 \\ and NBER \\ mdesai@hbs.edu
}

\author{
Joshua Rauh \\ MIT \\ Department of Economics \\ E52-300 \\ 50 Memorial Drive \\ Cambridge, MA 02142 \\ rauh@mit.edu
}




\section{Introduction}

Manipulation of reported earnings can be a powerful tool for managers to inflate their stock prices. Studies of earnings manipulation typically emphasize aggregate measures such as accruals and, consequently, struggle to link earnings manipulation to investment decisions. In this paper, we identify a simple mechanism for earnings manipulation, describe how manipulation through this channel is linked to CEOs' incentives, and show that firms change investment decisions in order to justify, and capitalize on, this type of earnings manipulation. Specifically, we find that managers opportunistically choose assumed rates of return on pension assets, and we examine how these distorted reporting decisions interact with option exercises, merger activity and asset allocation decisions within pension plans.

The size of defined-benefit pension plans and managers' wide latitude in characterizing them to capital markets make pension accounting a fertile area for earnings manipulation. Many firms have pension plans that are large enough to allow them to substantially increase reported earnings in the short run by changing the assumed long-term rate of return for the pension assets they manage for their workers. Managers who perceive that manipulating this assumption can influence their firms' stock price, as was apparently the case during the 1990s, face strong incentives to set this long-term rate of return assumption opportunistically.

Some capital market observers have viewed the actions of IBM, under CEO Louis Gerstner, Jr., as an example of how firms can use pension accounting to manipulate earnings. ${ }^{1}$ IBM sponsors a large defined benefit pension plan, with over $\$ 57$ billion in assets at the end of 2002. Table 1 outlines the operating performance of IBM, the performance of its DB pension plan, and the CEO's option grants and exercises. Changes in the long-term rate of return (LTROR) that IBM assumes on its DB pension plan assets are of particular interest. IBM changed its assumed long-term rate of return four times during this period: a twenty-five basis point reduction in 1995, a twenty-five basis point increase in 1997, a fifty basis point increase in 2000 , and a fifty basis point reduction in 2002. As we describe more fully in the sections that follow, IBM's assumed rates of return throughout this period exceeded those used by most firms. The frequent changes are also notable given the long run nature of these assets and assumptions.

\footnotetext{
${ }^{1}$ See Maclean (2002).
} 
While IBM reacted to poor actual performance in its pension plan in the mid-1990s by reducing the assumed long-term rate of return, the opposite occurred in 2000. Despite poor equity market returns and declining bond yields during that year, IBM raised its long-term rate of return assumption by fifty basis points. Nearly five percent of IBM's income before tax in 2000 and 2001 resulted from the increase in the assumed long-term rate of return from $9.25 \%$ to $10.00 \%$. More generally, IBM's reported pretax income grew at a compound annual growth rate of 6.7\% from 1995 to 2001; without these changes, income would have grown at only a 5.6\% rate. As Table 1 shows, these changes in pension assumptions coincided with deteriorating operating performance.

This example illustrates how senior managers can use pension accounting to boost their firms’ reported profits. Coronado and Sharpe (2003) present evidence that investors did not 'pierce the veil' of pension finance accounting during the 1990s; they show that earnings associated with changed pension assumptions were capitalized into prices to the same degree as operating earnings. ${ }^{2}$ Their results suggest that managers can boost both reported profits and stock prices through the simple mechanism of pension accounting. We investigate the degree to which managers are opportunistic with these assumed returns and evaluate the extent to which choices on assumed returns interact with their own option exercises and with the merger activity of their firms. Finally, we examine whether managers alter asset allocation within pension plans to justify these assumed returns.

In order to identify the relative incentive to use this lever of earnings manipulation, we begin by constructing a measure of the sensitivity of a firm's overall profits to the assumed longtem rate of return on pension assets. We show that this sensitivity measure is an important determinant of the levels of, and changes in, assumed rates of return. Specifically, a firm whose pension assets are twice as large relative to its operating income as the median firm in our sample makes a long-term rate of return assumption that is, on average, approximately ten basis points higher than the median. A firm in the $90^{\text {th }}$ percentile of sensitivity, on average, has a longterm rate of return assumption that is 40 basis points higher than a firm in the $10^{\text {th }}$ percentile. These differences in return assumptions can have an economically meaningful impact on

\footnotetext{
${ }^{2}$ In a related vein, Franzoni and Marin (2003) conclude that firms with underfunded plans are overvalued by the market.
} 
reported earnings for many firms: at the $90^{\text {th }}$ percentile of pension sensitivity, a 40 basis point increase in the LTROR assumption will raise a firm's reported earnings by $1.2 \%$. The estimated impact of these measures of pension sensitivity on rate of return assumptions grew significantly during the 1990s.

Having identified the opportunistic nature of these assumptions, the paper investigates the links between this form of earnings manipulation and firm and managerial investment decisions. We show that firms make particularly high return assumptions in periods leading up to the acquisition of other firms. This relationship is particularly strong for firms whose reported income is the most sensitive to pension assumptions. Assumed long-term rates of return are approximately 30 basis points higher for firms acquiring other firms. We show that this acquisition result cannot be explained by variation in actual lagged pension asset returns or by proxies for the optimism or aggressiveness of firms' CEOs. In addition, years in which CEOs choose to exercise options also are characterized by higher return assumptions. A one standarddeviation increase in option exercise at the median firm is associated with a 4 basis point increase in the assumed long-term rate of return. As managers prepare for acquisitions and for large exercises, they have an increased incentive to produce higher earnings and share prices and they appear to increase their assumed rates of return in order to do so.

The asset allocation decision within pension plans is another investment decision that might reflect this earnings manipulation. Allocations to equity vary considerably across organizational form and across firms, with equity allocations in firm-sponsored pension funds exceeding those in public and union-sponsored funds. Indeed, the large equity allocation in most firm pension plans is a persistent puzzle; our analysis suggests that the interaction of managerial opportunism and pension accounting may help explain part of this phenomenon as managers increase equity allocations to justify rate of return assumptions. Our empirical strategy is to regress equity allocation on the long-term rate of return assumption, using acquisitions as an instrument for the long-term pension asset return assumption. This method aims to address the concern that assumed rates and asset allocation decisions may be correlated for reasons unrelated to managerial motivations. Because it is unlikely that the variation in equity allocations is independently correlated with firm acquisition activity, this empirical approach provides a useful source of identification. The results from this IV analysis indicate that changed assumed rates 
lead to changed asset allocation decisions. Specifically, we find that 25 basis point increases in assumed rates are associated with 5\% increases in equity allocation. These results seem reasonable given that they are consistent with an assumed market risk premium of 5\%.

We conclude by framing our investigation of earnings manipulation within the debate on whether earnings manipulation reflects an agency concern or is beneficial to current shareholders. We show that managers who are the least constrained by their shareholders - as measured by an index of corporate governance - appear to be the most aggressive with their rate of return assumptions. This evidence suggests that the earnings manipulation investigated here does not benefit current shareholders. We go on to speculate on the magnitude of these effects by returning to the case of IBM. We estimate that between $\$ 12$ and $\$ 76$ million of compensation accrued to Gerstner from these changed assumptions alone.

Earnings manipulation is not the only factor that may affect firms' long-term rate of return assumptions. As discussed in Amir and Benartzi (1998), assumed rates of return might simply reflect the composition of pension plan assets, with higher assumed rates reflecting higher allocations to equity. However, Amir and Benartzi (1998) also suggest that this explanation for reported rates of returns is incomplete, and our robustness checks confirm this. A second possibility is that managers adjust the expected long-term rate of return on plan assets to be close to recent actual returns on plan assets, following a form of excessive extrapolation based on recent history (Benartzi (2001)). We find that lagged actual pension returns are positively correlated with the return assumption, but that the effects of acquisitions and earnings sensitivity are not attenuated in the presence of controls for this extrapolation effect. Third, it is possible that variation in assumed rates of return partly reflects heterogeneity in managerial optimism, with more optimistic managers and firms making higher rate of return assumptions. While we cannot reject the hypothesis that heterogeneous disposition might influence the distribution of the expected long-term rate of return assumption, we show that our sensitivity and acquisition results are robust to plausible controls for this factor - particularly pension fund asset allocations and the extent to which CEO compensation comes from option grants.

This work relates closely to the existing work on earnings management, summarized in Healy and Whalen (1999). Sloan (1996) finds evidence that the market 'misprices' accruals 
components of earnings, meaning that periods where accruals make up a large part of earnings are followed by low returns. Xie (2001) finds evidence that this result comes largely from discretionary components of earnings, suggesting that Sloan's result is related to managerial manipulation of earnings. ${ }^{3}$ Teoh, Welch, and Wong (1998a, 1998b) focus on discretionary accruals at times that firms are selling shares, and find additional evidence consistent with opportunistic managerial manipulation of accruals components of earnings.

In contrast to much of the existing work on earnings manipulation and managerial incentives, our analysis of the assumed rate of return on pension assets isolates a specific action that is otherwise unrelated to the core business of a firm. This approach avoids measures of earnings manipulation that are based on aggregate accounting variables, such as the difference between a firm's cash flow and its reported earnings. Such measures, because they are often correlated with firm growth rates, can lead to potentially spurious correlations with other variables related to firm growth rates. Our focus on pension accounting isolates earnings manipulation in a way that is less likely to be associated with a firm's core activities, and avoids these potential spurious correlations. Additionally, the results reported are robust to the inclusion of industry-year controls, and firm and year fixed effects, thereby supporting the underlying link we identify between managerial opportunism and earnings manipulation. Finally, additional robustness checks demonstrate that alternative theories of how firms set longterm rate of return assumptions - e.g. that these choices reflect equity allocations, excessive extrapolation from past returns, or managerial optimism — cannot explain our results.

In addition to the literature on the motivations for earnings manipulation, this paper relates to both the literature on incentive compensation and managerial incentives and to the literature on the asset allocation decisions and reporting of pension plans. As detailed in Hall and Murphy (2003), the growth of incentive compensation is one of the most notable developments in corporate practices through the 1990s. Recently, more attention has been paid to the less beneficial effects of such practices, as in Bebchuk, Fried and Walker (2002) and Bergstresser and Philippon's (2003) study of accrual accounting. Our evidence that firms make

\footnotetext{
${ }^{3}$ Chan, Chan, Jegadeesh, and Lakonishok (2001) focus on market evaluation of accruals components. Their evidence suggests that, even without earnings manipulation, the market misjudges the importance of key accruals components. For instance, reductions in accounts payable (which reduce accruals) forecast positive returns.
} 
more aggressive pension accounting decisions during periods where their CEOs are exercising stock options is consistent with the patterns of evidence documented in the papers listed above.

Academic work on pension plans has typically focused on whether or not firms incorporate pension plans into their own capital structure and investment decisions (as in Friedman (1983) and Bodie et al. (1985)), how unfunded pension liabilities are priced by the market (see for example Feldstein and Seligman (1981) and Feldstein and Mørck (1983)), and how firms react to the guarantee of pension liabilities provided through the Pension Benefit Guarantee Corporation. Some studies have examined latitude in setting the rate used to discount pension liabilities in accounting regimes where this flexibility was considerable. ${ }^{4}$ Several studies have examined asset allocation decisions (eg. Papke (1992)) and their relationship to tax incentives, as in Frank (2002). The earlier-mentioned paper by Amir and Benartzi (1998) examines expected rate of return assumptions and find them weakly related to equity shares and unrelated to future performance of pension fund assets. Gold (2003) conjectures that the puzzle of high equity allocations in defined-benefit pension plans reflects managerial incentives created by accounting rules and our results investigate and confirm this conjecture.

Section 2 motivates our analysis with an example that illustrates how the defined-benefit pension plan long-term rate of return assumption can affect reported income. Section 3 describes recent patterns on assumed rates and asset allocation and reviews the data employed in the subsequent analysis. Section 4 analyzes the determinants of assumed rates of return with particular emphasis on the role of merger activity and incentive compensation. Section 5 relates decisions on assumed returns on pension assets to equity allocation decisions through and instrumental variables analysis. Section 6 discusses the consequences of these results for the evolving debate on how managerial manipulations reallocate value amongst current shareholders, potential shareholders and managers. Section 7 concludes.

\section{A motivating example}

A firm that sponsors a DB pension plan creates a liability equal to the present value of all future payments due their employees. Firms fund these liabilities with devoted pension assets,

\footnotetext{
${ }^{4}$ Feldstein and Mørck (1983) consider these assumptions in the US before SFAS 87, which placed significant restrictions on discount rates. Obinata (2000) considers Japanese firms.
} 
which by law are to be managed in the interest of the employee-beneficiaries. These assets and obligations, however, are accounted for on the firm's financial statements. Explicit rules dictate contribution and funding decisions, such as minimum funding requirements and restrictions designed to prevent substantial overfunding of plans. Yet firms have significant latitude to make assumptions when they report to capital markets the cost of sponsoring the plan, as well as the value of the plan's assets and liabilities. ${ }^{5}$ We focus on these assumptions and their impact on asset allocation in the sections that follow.

Firms make three main calculations when characterizing the annual cost of their DB plans - a service cost, an interest cost, and an offsetting assumed return on plan assets. The service cost is the present value of benefits earned by the firm's employees during the current period. This cost is the change in the value of the firm's promises to its employees that comes from an additional year of employment. ${ }^{6}$ Firms also report an interest cost corresponding to the change in the present discounted value of the pension obligations arising from the approach of the discharging of these obligations. Holding constant the nominal value of the obligations, bringing these obligations a year closer increases their present discounted value. The interest cost would also include the change in the present discounted value of pension obligations due to changing interest rates. Industry observers suggest that individual firms have relatively limited discretion over their reported service and interest costs. ${ }^{7}$

The final component of pension expense, the assumed return on plan assets, offsets the interest and service costs. This return is an assumed return rather than the realized rate of return on the plan's assets. Using an assumption insulates annual earnings from year-to-year fluctuations in the market performance of pension assets. Managers enjoy significant discretion

\footnotetext{
${ }^{5}$ For a detailed discussion of these accounting rules, see Hawkins (2001) and Zion and Carcache (2002). For a broader discussion of the legal rules surrounding DB plans, see Langbein and Wolk (2000).

${ }^{6}$ When an employee's wages grow with tenure, and when the promised benefits of the DB plan are a function of wages in the final years of employment, the reported service cost captures the cost arising from an additional year of wage growth for covered employees.

${ }^{7}$ See Zion and Carcache (2002). In 1993, the SEC's Chief Accountant determined that the discount rate for pension liabilities should be based on the Moody's Aa interest rate index. While some discretion remains, based, for instance on the interaction between the slope of the yield curve and demographic differences across firms (differences in the age structure of pension plan participants give pension liabilities different effective durations across firms), discount rates since that ruling have been much more tightly bunched than was previously the case. Recent steep declines in these rates have raised liabilities while asset values of equity-heavy pension funds have fallen, a situation industry insiders call the "Perfect Storm".
} 
in setting the assumed long-term rate of return used for financial reporting purposes. ${ }^{8}$ The reconciliation between the assumed and actual rates of return happens over time, with potentially very long amortization periods. ${ }^{9}$ This arrangement provides managers of firms with large pension funds relative to the size of operating earnings with a substantial opportunity to manage earnings.

As a simple example, consider a firm with \$100 of operating assets, a 4\% (\$4) return on these operating assets, and $\$ 20$ of pension assets. If this firm changes the assumed rate of return from $10 \%$ to $11 \%$, it can immediately increase net income by $5 \%$ (or $\$ 0.20$ ). As this example illustrates, the scope for increasing profits in this manner is a function of the size of pension assets relative to operating income.

Table 2 presents a matrix, showing for different levels of pension sensitivity (across the columns) and different long-term rate of return assumptions (down the rows) the share of nonpension operating income that arises from the assumed return on pension assets. Our measure of pension sensitivity is the ratio of pension assets to firm operating income, and the long-term rate of return is the one reported in the firm's financial statements. The particular row entries in the table reflect the distribution of long-term rates of return in the Compustat-based sample used in the empirical work that follows; the fifth percentile is 7 percent, while the median is 9 percent and the $95^{\text {th }}$ percentile is 10 percent. The column entries in the table reflect the distribution of pension sensitivity; at the median firm in our sample, pension assets amount to 71.6 percent of firm operating income.

\footnotetext{
${ }^{8}$ The firm can actually make different long-term rate of return assumptions for a given year, depending on the audience: firms' actuaries choose the long-term rate of return assumption used to determine its minimum pension funding requirements under federal law. This long-term rate of return assumption is not reported to financial markets and has no impact on the firm's reported earnings. The long-term rate of return assumptions used in firms' financial reports are chosen by the firms themselves, rather than their actuaries. These long-term rate of return assumptions affect the firms' reported earnings, and conversations with industry participants suggest that these longterm rate of return assumptions have been higher than the long-term rate of return assumptions chosen by the firm's actuaries for determining compliance with federal pension funding standards.

${ }^{9}$ Any deviation between actual realized returns and the actuarial assumption enters an off-balance sheet item 'unrecognized gain or loss'. The rules for amortization of this unrecognized component are based on a 'corridor' approach; as long as the unrecognized component is less than 10 percent of the PBO, there is no need to amortize any part of the difference. When the unrecognized component is beyond 10 percent of the PBO, a firm is required to amortize a share of the difference between their position and the 10 percent 'corridor' boundary. The required share is based on the expected future service of the plan's participants.
} 
For the firms with small plans, even large changes in the assumed rate of return make only small differences in net earnings. For instance, at the $10^{\text {th }}$ percentile of pension sensitivity, at which plan assets amount to 5.8 percent of firm operating income, changing the assumed rate of return from 7 percent to 10 percent would boost reported income by only 2 tenths of a percent. However, at the $50^{\text {th }}$ percentile of pension sensitivity, the same increase in the assumed rate of return would increase reported income by over 2 percent. At the $90^{\text {th }}$ percentile of pension sensitivity, reported firm income would rise by almost 9 percent. Firms with large pension plans, such as IBM, can significantly change their reported performance by adjusting this assumed long-term rate of return. ${ }^{10}$

The desire to manipulate assumed rates of return may have an influence on pension asset allocations. Extreme rate of return assumptions may be easier to justify in a setting where expected returns are more uncertain. In particular, the uncertainty involved in equity returns means that a firm with a large equity allocation enjoys greater leeway in estimating expected returns than a firm whose investments are entirely in fixed-income securities. In short, higher assumed returns may be more easily rationalized with higher equity allocations. The following sections explore the link between long-term rate of return assumptions and managerial motivations in order to identify the role of opportunism relative to alternative explanations in determining reporting decisions. In particular, we focus on the incentives to raise reported earnings in periods around option exercise and in periods when firms are purchasing other companies.

\section{Data and descriptive statistics}

To examine the links among managers' motivations and pension reporting and asset allocation decisions, we compile data from several sources. Firm non-pension income, nonpension assets, pension fund size, pension liability size, and long-term rate of return assumptions for pension assets come from the Compustat dataset for the years 1991-2002. Compustat Executive Compensation provides information on CEO option exercise for a subsample of Compustat firms from 1992-2002. We take data on firm acquisitions from the Securities Data

\footnotetext{
${ }^{10}$ Not all firms with large pension plans actively change their assumed rates of return. Appendix Table 1 details the assumed rates of returns for the ten largest DB sponsors, other than IBM, as provided in their 10-Ks. This table
} 
Company (SDC) database of mergers and acquisitions and are available for the entire sample period.

Pension fund asset allocation data come from two sources. First, an annual survey conducted by Pensions and Investments covers the asset allocation of the largest US pension funds from 1991-2002. ${ }^{11}$ Second, firms sponsoring pension plans with more than 100 employees must file a Form 5500 for each plan with the IRS on an annual basis; the full set of these forms are publicly available in electronic form through 1998 and contain asset allocation data. For firms with multiple plans we aggregate the IRS 5500 filings from the plan-year level to firm-year observations. We do not use asset allocation data from a firm's 5500 filings if that pension fund's assets are held in trusts or other opaque investment vehicles; for these observations it is impossible to precisely identify equity allocations. The combination of the Pensions and Investments and IRS 5500 sources provides equity allocation information for approximately 3,200 firm-year observations, and approximately equal numbers of firm-year observations come from each of the two sources. ${ }^{12}$

The analysis that follows uses three different samples; the second and third are subsets of the first. Our primary sample includes all Compustat firms for which pension assets, operating income, and assumed long-term rates of return on pension investments are available. ${ }^{13}$ This sample has 19,325 observations for 3,247 defined-benefit plan sponsors during this period. We use this sample to investigate the relationships among pension sensitivity, firm acquisitions, and assumed rates of return on pension assets. The second sample includes the 7,075 firm-year observations from the first sample that can be linked to the Compustat Executive Compensation database. We use this smaller sample to investigate the role of executive option exercises. The third sample includes the 3,202 firm-year observations from the first sample for which we also

demonstrates that several of these large firms never change their rates of return and others change their assumed rates of return often.

11 The Pensions and Investments survey data begins in 1988 but the years 1988-1990 are not used in this study as the Compustat pension data does not begin until 1991.

12 The initial size of the $P \& I$ sample is 200 pension sponsors for each year 1988-1996 and 1000 sponsors for $1997-$ 2002. Approximately $45 \%$ of the entities in each year of the $P \& I$ are corporate (as opposed to public, union, or nonprofit) sponsors of DB plans. The requisite data from Compustat (in particular the long-term rate of return) are available for approximately two-thirds of those observations, leaving about 1,700 P\&I observations at the firm-year level. The IRS 5500 filings add the remaining 1,500 observations during the period 1990-1998, which is also the period for which the Pensions \& Investments sample is smaller. 
observe pension fund asset allocations, either from the Pensions and Investments data or from the IRS 5500 filings. We use this sample to investigate the relationship between long-term rate of return assumptions and pension fund asset allocations.

Defined benefit pension plans are quite large in aggregate, and represent a significant part of overall assets for corporate sponsors. These assets also represent a large part of the pool of liquid financial assets in the economy. Table 3 describes the sizes of these plans among the firms in our sample. The aggregate ratio of pension assets to operating assets peaked at $10.31 \%$ in 1997 when pension assets totaled \$1.156 trillion for the 1,630 firms in the sample. The mean firm in our sample, in that year, had $\$ 709.4$ million in pension assets. The distribution is highly skewed, however; the median in 1997 year was $\$ 77$ million and the $95^{\text {th }}$ percentile was $\$ 414.6$ million.

The market value of pension fund assets declined recently along with broader equity markets. In 2002, the total pension fund assets for the 1,502 sample firms totaled \$1.094 trillion, an amount equal to 5.7 percent of balance sheet assets. This reduction in the value of pension assets coincided with increasing plan liability values due to falling bond yields, a situation that has caused the deterioration in the funding status of our sample of defined benefit pension plans documented in Figure $1 .^{14}$ This figure shows the mean, median, and $25^{\text {th }}$ and $75^{\text {th }}$ percentile funding status among our sample of funds, measured along the left axis.

In 1991 the mean and median funds were both overfunded, as the value of pension assets exceeded the estimated value of pension liabilities. At the $25^{\text {th }}$ percentile fund, the extent of underfunding amounted to over 10 percent of plan liabilities. At the height of the market peak in 1999 , the $75^{\text {th }}$ percentile plan was 30 percent overfunded, and the $50^{\text {th }}$ percentile plan was more than 10 percent overfunded. While at the end of 1999 recent equity returns had been very high, the impact of these returns on pension plan funding status was partially offset by increases in pension liabilities due to falling bond yields. By 2002, several years of poor equity market performance and declining bond yields had degraded the funding status of defined benefit pension plans; in this year, the median and mean pension plans in the sample were almost 25

\footnotetext{
${ }^{13}$ This sample includes only those firms for which the log ratio of pension fund size to firm operating income can be computed.
} 
percent underfunded. This underfunding has raised policy concerns given the role that the federally-sponsored Pension Benefit Guarantee Corporation plays in insuring pension plan participants, as well as the cash drains that required contributions represent to firms with underfunded plans. ${ }^{15}$

Asset allocations for the firms in our sample have shifted over time. Figure 2 plots the allocations to equity among the firms in our sample, as well as additional samples of unionsponsored and public-sponsored pension plans covered in the Pensions and Investments annual surveys. Two distinct patterns emerge. First, the mean allocation to equity in each of the three types of pension funds increased fairly dramatically over the period. Among the corporatesponsored plans in our sample, the mean allocation to equity rises from 35 percent to approximately 65 percent between 1991 and 2000, before retreating in 2001 and 2002. The second pattern is that the increase in equity allocations at corporate-sponsored pension plans has been particularly dramatic relative to union or public plans. Obviously, greater exposure to equities has contributed to the current funding crisis apparent in Figure 1. Section 5 of this paper explores the relationship between managerial incentives and the shift of pension assets towards equity over the 1990s.

The cross-sectional distribution of long-term rate of return assumptions has been relatively constant during this period of changing yields and shifting returns. Figure 3 documents the median long-term asset rate of return assumptions in our sample of pension funds. The median assumed return is constant at 9 percent until the last period of the sample, when it falls to 8.5 percent. The mean, $25^{\text {th }}$ percentile, and $75^{\text {th }}$ percentiles of the distribution have also been roughly constant through the period. This stable distribution of long-term rate of return assumptions is striking because yields on Treasury securities have been declining; the lowest line on Figure 3 shows the yield on 10-year government bonds over the period. Because firms generally hold a mix of equity and fixed-income securities, this constant median LTROR assumption has implied increasing optimism about the contribution to total returns from the equity components of firm pension plans. The top line on Figure 3 gives the implied assumed expected return on the equity securities held in a pension fund that is 40 percent equity 60

\footnotetext{
${ }^{14}$ We use the projected benefit obligation (PBO) as our measure of liabilities and compute funding status as the difference between plan assets and plan liability scaled by plan liabilities.
} 
percent bonds and that assumes an aggregate long-term rate of return of 9 percent; at this ratio, the implied expected return on equity, based on bond yields, was approaching 16 percent by 2002. ${ }^{16}$ A forward-looking expected return of 16 percent on an equity portfolio is optimistic by most measures. ${ }^{17}$

The constant cross-sectional distribution of long-term rate of return assumptions over this period does not mean that individual firms' assumptions have been fixed. Table 4 documents the pattern of increases and decreases to long-term rate of return assumptions over our sample period. Roughly 30 percent of the firm-year observations over this period see either a decrease or an increase in the assumed long-term rate of return. Increases in the assumed long-term rate of return are more common during the late 1990s, while decreases are more common in the early 1990s and 2001 and 2002. Nonetheless, the fact that increases and decreases are represented in all years is indicative of the latitude exercised by managers in setting this rate. Even in the difficult market environment of 2000-2002, a significant fraction of firms increased their rate of return assumption.

In order to assess the role of managerial opportunism, we begin by emphasizing the measure of pension sensitivity developed earlier — the logarithm of the ratio of pension assets to operating income in a firm year. This measure excludes observations with negative operating income; employing the log of the ratio also collapses the influence of outlying observations and brings the distribution of pension sensitivity closer to that of a normally distributed random variable. This measure has the advantage of capturing the variation across firm-year observations in the incentive to manipulate the long-term rate of return. Unfortunately, because the numerator of this measure reflects, in part, realized returns to pension assets, it may be linked mechanically to assumed returns. Specifically, firms with abnormally high returns, and thus pension assets, may use these realized returns as a basis for increasing assumed returns. Given that this feedback mechanism need not be a reflection of managerial opportunism, we employ two alternative measures of pension sensitivity that are not susceptible to this bias. Specifically, the second measure of pension sensitivity uses the ratio of the firm's average pension assets, over

\footnotetext{
${ }^{15}$ See Rauh (2003).

${ }^{16}$ Among the firm-year observations in 2002 for which we observe equity allocation and for which that allocation lies between 0 and 40 percent, 9.0 percent is the median long-term rate of return assumption.
} 
the 1991-2000 period, to operating income. Annual observations of this measure will not be driven by differences in the return to pension assets across years. The third measure of pension sensitivity is the log of the ratio of pension liabilities to firm operating income. Using pension liabilities rather than assets completely removes the impact of pension asset returns on the sensitivity measure, and also addresses potential feedback from the size of the pension fund to the long-term rate of return assumption.

Table 5 describes these variables as well as the others used in the empirical analysis. At the mean, pension assets are $\$ 653$ million and operating assets are $\$ 7,302.5$; because of the skewness of the size distribution of firms these means are substantially higher than the median pension assets (\$65.5 million) and operating assets (\$911.7 million). At the median, pension assets are 71.6 percent of operating income and 8.6 percent of operating assets. The next rows in Table 4 describe our three measures of pension sensitivity. For the first measure of pension sensitivity, the log ratio of pension assets to operating income, the median is -0.334 and the mean is -0.440 . The distributions of the other two pension sensitivity measures are roughly similar; the mean of the second measure is -0.446 and the mean of the third is -0.382 .

The next several rows of Table 5 describe our acquirer indicator and CEO option exercise variables. We use these variables in our analysis of firms' motivations for aggressive long-term rate of return assumptions, looking in particular at the level of the LTROR assumptions during periods where firms' CEOs may particularly want to boost reported earnings. We classify 26.1 percent of our firm-year observations as 'acquirers.' Our timing convention is to identify a firmyear observation as an 'acquirer' if that firm reports the acquisition of another firm in that year. We use this timing convention because firms' LTROR assumptions are set prior to the fiscal year, and will begin impacting reported earnings starting with the first quarter of the fiscal year. In addition, the LTROR assumption may begin impacting firms' prices immediately through the earnings 'guidance' that firms give to analysts throughout the year.

Among the 7,075 firm-year observations that we are able to link to Compustat Executive Compensation data, CEO option exercises as a share of firm market value averages 30 basis points. About 32 percent of firm-year observations see CEO option exercise; among these

\footnotetext{
${ }^{17}$ Welch (2001) surveys 510 finance and economics professors and reports that the mean 30-year stock market
} 
observations, the median option exercise value as a share of the firm's value is 24 basis points. In addition to scaling the value of CEO option exercise by the market value of the firm's equity, we also present results that scale CEO option exercise (and grants) by the CEO's own option holdings. The goal in this approach is to provide an additional control for cross-firm heterogeneity in the importance of option compensation. The number of options exercised by the CEO in a year, as a share of the total held, averages 10.5 percent among the CEOs in our sample. The number of options granted as a share of the number of options held averages 26.4 percent in our sample.

\section{The determinants of assumed returns}

The empirical work in this section assesses the determinants of long-term rate of return assumptions with particular emphasis on the links to the sensitivity measure and on the periods around mergers and large option exercises by senior managers. Table 6 reports the results of linear regressions of firm-year assumed long-term rates of return on covariates, including pension sensitivity measures and year and industry controls. These regressions focus on assessing whether reported long-term rates of returns are higher at those firms where reported earnings are more sensitive to the rate of return assumption.

\section{(1) Assumed Rate of Return $n_{i, t}=\alpha+\beta *$ Log Pension Sensitivity ${ }_{i, t}+X_{i, t}^{\prime} \Gamma+\varepsilon_{i, t}$}

We correct reported standard errors for clustering at the firm level. The first column of Table 6 reports the results of an OLS regression of assumed long-term rates of return on the first measure of pension sensitivity, the log ratio of annual pension fund assets to annual firm operating income. With no covariates, the coefficient on the pension sensitivity measure is 0.113 . This implies that a movement from the $25^{\text {th }}$ percentile of log pension sensitivity $(-1.21)$ to the $75^{\text {th }}$ percentile (0.40) would be associated with an 18 basis point increase in a firm's reported longterm rate of return. The second column of Table 6 includes a time trend and the interaction of the time trend with pension sensitivity. The results in this column suggest that the impact of sensitivity on the long-term rate of return assumption increases over the sample: the implied

return forecast in this group is 9.1 percent; responses to this survey bunch tightly between 8 and 10.5 percent. 
impact of pension sensitivity is 0.072 in the first year of the sample and 0.171 by the end of the sample.

Columns 3 through 6 of Table 6 explore the robustness of the relationship between pension sensitivity and the long-term rate of return assumption to controls for year effects, industry effects, year and industry effects, and year-by-industry effects. Of these, column 6 has the most generous control structure, allowing a separate dummy variable for each of 48 industry groups in each year. The estimated coefficients on our first measure of pension sensitivity are not affected by these additional controls. The point estimate of the coefficient ranges from 0.109 in the specification with year fixed effects to 0.123 in the specification with 48 industry effects.

The final two columns of Table 6 explore the two other measures of pension sensitivity and provides for industry-by-year effects as in column 6. Column 7 uses the average of pension asset size over the period as a numerator in the measure of sensitivity, and provides a coefficient roughly similar to those produced in the specifications presented in columns 1 through 6 . Finally, column 8 uses the log ratio of pension liability size to firm operating income. The results are not statistically distinguishable from the results using our main sensitivity measure, suggesting that the effect we observe is not merely the result of managers adjusting the long term rate of return to correspond with recent past actual investment returns.

If managerial opportunism is important in determining assumed long term rates of return, this relationship should be heightened when managers are most interested in inflating profits and stock prices. Figure 4 presents a preliminary exploration of the relationship between takeover activity and long-term rate of return assumptions, describing the pattern of return assumptions around periods that firms undertake merger. Each point on the figure corresponds to a separate regression (with 2-standard error bands on either side); these regressions fit firm-year long-term rate of return assumptions on dummy variables for calendar year as well as an additional dummy variable capturing takeover activity. Each date on the graph corresponds to a separate regression with a different dummy variable; the date (-5), for instance, corresponds to a regression with a dummy variable set equal to 1 if the firm is not doing a takeover in this year, but will do a takeover in 5 years. The date (0) corresponds to a regression where the dummy variable is equal to one for all firms that take over other firms in that year. This marks only a preliminary 
exploration of the data, but the results are revealing. First, firms that will eventually engage in merger activity do appear different from other firms. Conditional only on takeover activity in 5 years and none in the current year, long-term rate of return assumptions are almost 15 basis points higher than their unconditional expectation in the complementary group of firms. However, firm long-term rate of return assumptions are almost 30 basis points higher during merger years than during other years.

Table 7 pursues this line of investigation further, reporting results with different sets of control variables. We use a dummy variable that is set equal to one when the firm makes an acquisition of another publicly-traded firm in that year. This dummy variable captures potential managerial motivations to inflate reported earnings in order to boost their companies’ share prices prior to acquisition activity. In addition, we include the interaction of our acquirer dummy with pension sensitivity. The motivation behind including these variables is to explore long-term rate of return assumption during periods when firms have particularly strong incentives to inflate their earnings, and the interaction identifies the effect at firms where the assumption could have a larger impact on reported income prior to an acquisition.

Equation 2 gives the estimated empirical model for the analysis in Table 7:

$$
\begin{gathered}
\text { (2) Assumed Rate of Return } \text { R }_{i, t}=\alpha+\beta * \text { Log Pensions Sensitivity }_{i, t}+\delta^{*} \text { Acquiror Dummy }_{i, t} \\
+\lambda *(\text { Log Pensions Sensitivity } \\
\left.+ \text { Acquiror Dummy }_{i, t}\right)+X_{i, t}^{\prime} \Gamma+\varepsilon_{i, t}
\end{gathered}
$$

The results in Table 7 suggest that firms make more aggressive long-term rate of return assumptions during periods when they are acquiring other firms. The magnitude of this effect among firms within an industry-year is large. Firms that are one period before making an acquisition on average have assumed a long-term rate of return that is around 30 basis points higher than other firms in all of the specifications. In the fixed effects specification, this effect is smaller, but is still statistically significant, with a point estimate of 3.5 basis points on the acquirer dummy and a point estimate of 3.7 basis points on the interaction term. With firm and year effects, $\delta$ has a point estimate of 4.6 basis points and $\lambda$ a point estimate of 4.6 basis points.

These results support the hypothesis that the tendency to raise the return assumption is greater for firms where changes in the LTROR assumption have a higher impact on operating 
income. At firms where the pension sensitivity is higher, the marginal impact of the acquisition dummy is also greater. The coefficient on the interaction term is between 0.037 and 0.072 and statistically significant in each of the specifications. Taking an estimated coefficient of 0.06 would imply that the marginal impact of the acquisition dummy on the rate of return assumption is 10 basis points higher at the $75^{\text {th }}$ percentile of log pension sensitivity than at the $25^{\text {th }}$ percentile.

For the specifications with industry-by-year effects, the point estimates on the takeover dummy and the interaction term imply that at the $25^{\text {th }}$ percentile of pension sensitivity, the longterm rate of return assumption is 25 basis points higher in the period before acquisitions. At the $75^{\text {th }}$ percentile of the distribution of pension sensitivity, the estimates suggest that the return assumption is 37 basis points higher in the period before an acquisition. For the specifications that include both year and firm fixed effects, reported in column 6 of Table 7, the estimates appear smaller in magnitude. At the $25^{\text {th }}$ percentile of the pension sensitivity measure, the longterm rate of return assumption is about the same as usual during the acquisition period under the specification with firm and year fixed effects. At the $75^{\text {th }}$ percentile of the distribution of pension sensitivity, the return assumption in the acquisition year is estimated to be six basis points higher than firm average. At the $90^{\text {th }}$ percentile, the coefficients suggest that the return assumption is nine basis points higher.

While the point estimates in the specifications with fixed effects may appear small in magnitude, these estimates are consistent with opportunistic adjustments to the long-term rate of return assumptions that are economically meaningful. First, while the standard deviation of the long-term rate of return assumption in the entire sample is 111 basis points, the within-firm standard deviation is only 63 basis points. The magnitude of estimated coefficients in specifications with firm fixed effects should be compared to the within-firm rather than the cross-sectional standard deviation of the long-term rate of return assumption. Second, increases in the LTROR most commonly occur in 25 basis point increments. A point estimate of six basis points at the $75^{\text {th }}$ percentile of sensitivity is consistent with a given firm of that sensitivity having a higher LTROR for one in four acquisitions. Third, the fact that the magnitude of the estimated effect is higher at firms with higher pension sensitivity implies that the earnings generated by opportunistic adjustments to the LTROR assumption around acquisitions are greater than would 
be the case if the magnitude of the effect was the same across different levels of pension sensitivity. Finally, specifications with firm fixed effects effectively remove all cross-firm variation and consider only the effect of within firm variation in the acquisition indicator on the long-term rate of return assumptions. Specifications that include industry-by-year effects instead of firm-fixed effects allow some inference in the cross section. Comparing two firms in the same industry and the same year, one of which makes an acquisition and the other of which does not, the result says that the acquirer's expected long-term rate of return is 34 basis points larger.

Table 8 presents specifications designed to test the robustness of the acquisition results. There are three pairs of specifications. Within each pair, the specification to the left includes industry-by-year controls and the specification to the right includes firm level fixed effects. Columns (1) and (2) assess the robustness of the acquisition results to the inclusion of a variable capturing the share of the pension fund assets allocated to equity. An indicator variable set equal to one if the equity share variable is unavailable for that observation is included, as well as its interaction with the sensitivity variable are included in this specification (coefficients not shown). For every additional ten percentage points of pension fund assets allocated to equity, the assumed long-term rate of return is 8.5 basis points higher in the specification that controls for industry-by-year effects. In the within-firm specification, the coefficient on the equity share is not significantly different from zero. Most importantly, however, the coefficients on the acquisitions variables are essentially unchanged relative to the comparable results from Table 7 (columns (2) and (6)).

Columns (3) and (4) of Table 8 test the robustness of the results to the inclusion of lagged 12-month actual returns on pension assets. We use a procedure similar to columns (1) and (2), with an indicator variable included if the data item is missing. ${ }^{18}$ In column (3) an additional ten percentage points of lagged actual return is correlated with an assumed long-term rate of return that is 10 basis points higher. However, this effect is again not present in the within-firm specification, and in both specifications the point estimates on the acquisitions variables are very close to the comparable results from Table 7.

\footnotetext{
18 This variable is present in Compustat (data item 333) for most observations in our sample, but is incorrect starting in 1998 and therefore must be assumed missing for 1998-2003. Starting in 1998, data item 333 represents the expected earnings on plan assets, not the actual.
} 
Columns (5) and (6) of Table 8 examine the robustness of the results to a control for the optimism or aggressiveness of the firm's senior management. Specifically, we include CEO option grants as a share of the CEO's total salary. Our intuition in doing so is that a higher weight on options in a CEO's compensation package may be correlated with aggressive and optimistic managerial disposition. There is in fact a small positive correlation between this measure and the long-term rate of return assumption, although this disappears in the presence of firm fixed effects. The size of the acquirer coefficient is $50 \%$ smaller in column (5) than in columns (1) and (3), and the difference is statistically significant; but the acquirer coefficient in the fixed-effects specification is statistically the same as in columns (2) and (4). ${ }^{19}$

Given the emphasis on changes in assumed rates of returns, it useful to analyze these decisions directly with discrete dependent variables. Table 9 reports results of ordered probit regressions, where the dependent variables are categorical variables that reflect changes in assumed long-term rates of return. In the first two columns, the specification of the dependent variable is coarse: $(-1)$ if the firm decreases the long-term rate of return assumption in that year, (0) if it is unchanged, and (1) if the firm increases its rate of return assumption. This ordered probit model is based on a latent regression model of the following form:

\section{(3) $\triangle$ Assumed Rate of Return $i_{i, t}=\alpha+\beta *$ Log Pensions Sensitivity $_{i, t}+\delta^{*}$ Acquiror Dummy $_{i, t}$ $+\lambda *\left(\right.$ Log Pensions Sensitivity ${ }_{i, t}^{*}$ Acquiror Dummy $\left.{ }_{i, t}\right)+X_{i, t}^{\prime} \Gamma+\varepsilon_{i, t}$}

The latent propensity to change the long-term rate of return assumption is unobserved, but we do observe the actual changes:

(3') $\operatorname{SIGN}\left(\right.$ Assumed ROR $R_{i, t}$-Assumed $\left.R_{0 R} R_{i, t-1}\right)=-1$ if $\quad \triangle$ Assumed $R O R_{i, t}^{*} \leq 0$

$$
\begin{gathered}
0 \text { if } 0<\Delta \text { Assumed } R O R_{i, t}^{*} \leq \mu_{1} \\
1 \text { if } \mu_{1}<\Delta \text { Assumed } R O R_{i, t}^{*}
\end{gathered}
$$

The results in column 1 suggest that firms are more likely to increase their long-term rate of return assumption in periods where the pension sensitivity measure is highest; the results in

\footnotetext{
${ }^{19}$ The results are similarly robust when the magnitude of CEO share ownership in millions of dollars is used as a control.
} 
column 2 suggest that firms are likely to increase their long-term rate of return assumptions when they are making acquisitions. In particular, the acquirer coefficients can be translated into marginal effects for the probability of each action (increase, decrease, and no change). Firms are 1.2 percentage points less likely to reduce their long-term rate of return the year before an acquisition; 0.3 percentage points more likely to keep it the same; and 0.9 percentage points more likely to raise the rate. In the context of an overall $9.2 \%$ probability of a rate increase and a 14.1\% probability of a rate decrease, these magnitudes are rather significant. Columns 3 and 4 of Table 9 use a more nuanced, but still discrete, dependent variable: the variable takes on one of 11 different categories, ranging from large decreases in the assumed long term rate of return to large increases. The results are consistent with those in the first two columns. The standard errors for these results are clustered at the firm-level.

The results in columns 5 and 6 of Table 9 use our second measure of pension sensitivity as the independent variable: the measure used, for each firm-year observation, is the log ratio of the average pension fund size for that firm over the 11 years of the sample to the firm's operating income in that year. In these regressions, both the pension sensitivity measure and the takeover variable remain statistically significant. Similarly, the final two columns use the third definition of sensitivity, namely the log ratio of pension liabilities to the firm's operating income in a given year. The sensitivity variable does not predict changes in the long-term rate of return in this specification, but firms about to make acquisitions are more likely to raise their rate of return assumptions. The magnitude of the acquirer effect and the marginal effects are roughly constant across the specifications using different measures of the sensitivity. ${ }^{20}$

In order to further identify the role of managerial motivations, we turn finally to the link between option exercises and assumed rates of return. Table 10 and Figure 5 shift to a smaller sample of firms for which we observe executive compensation and option exercise data in addition to data on pension assets and rate of return assumptions. As with our analysis of merger

\footnotetext{
${ }^{20}$ We further considered the possibility that particular types of mergers - stock financed mergers - would be more closely associated with increases in assumed returns. This investigation is clouded by empirical and conceptual difficulties. First, our source on merger data has coarse groupings on the type of financing and manual inspection of the data for one company, IBM, relative to their 10-K's suggests only a crude mapping between the two sources. Second, as Fama and French (2003) point out, equity issuance through mergers is isomorphic with other forms of equity issuance and may be associated with additional monitoring costs further clouding the predicted relationship between merger financing and pension decision-making. The results do not indicate a distinctive pattern of assumed rates of return for stock-financed mergers.
} 
activity, we begin with a graphical depiction of our results in Figure 5. This figure, as with Figure 4, presents the coefficients from regressions of long-term rate of return on a dummy variable for CEO option exercise as well as calendar year dummy variables. The CEO option exercise dummy variables are set equal to 0 or 1 depending on whether options will be exercised at the appropriate lead or lag. While not as pronounced as Figure 4, the results do suggest a spike in long-term rate of return assumptions around periods of option exercise; at firms where the CEO is exercising options in the current year, long-term rate of return assumptions are 12 basis points higher than at other firms.

The first columns of Table 10 refine this analysis by estimating equations that allow us to incorporate different sets of control variables. The linear regression models reported in this table estimate equation 4 below:

$$
\begin{aligned}
& \text { (4) Assumed } \text { ROR }_{i, t}=\alpha+\beta * \text { Log Pensions Sensitivity }_{i, t}+\delta * \frac{\text { CEO Option Exercise Value }}{\text { Firm Equity Value }} \\
& +\lambda *(\text { Log Pensions Sensitivity } \\
& +{ }_{i, t}
\end{aligned}
$$

Again, we correct the standard errors in the table for clustering at the firm level. The results suggest that firms make aggressive long-term rate of return assumptions during periods when CEOs are exercising large amounts of stock options. Column (1) presents results with industry and year fixed effects, column (2) results with firm fixed effects, and column (3) results with firm and year fixed effects. The specification with firm fixed effects is designed to address the potential critique that the firms that use substantial option compensation are cross-sectionally different from other firms, and different in a way that is correlated with reported optimism about long-term rate of return assumptions.

The coefficient estimates range from 0.014 in the specification with firm fixed effects to 0.028 in the specification with industry by year effects. A coefficient estimate of 0.020 would imply that a one-standard deviation increase in exercise (1.780) would be associated with a 3.5 basis point increase in the assumed rate of return on pension assets. Again the marginal effect is larger at firms where pension sensitivity is larger; in the first specification, the coefficient of 0.013 on the interaction term implies that at the $25^{\text {th }}$ percentile of pension sensitivity the 
marginal effect of CEO option exercise is 0.013 . At the $75^{\text {th }}$ percentile of pension sensitivity estimated marginal effect of CEO option exercise is 0.032 .

The remaining two columns explore a different way to control for potentially spurious correlation between firms' propensity to compensate executives through options and firms' optimism about long-term rates of return. These columns use measures of CEO option exercise and grants that are normalized by the number of options held by the CEO. The goal here is to control for cross-sectional differences in firms' tastes for option compensation. Column (4) uses these independent variables in a specification with firm and year fixed effects. In this specification the coefficient on normalized option exercise, 0.041 , is positive and statistically significant, and the coefficient on option grants is negative with a t-statistic of 1.55. This suggests that long-term rate of return assumptions are unusually high at firm-year observations where the CEO is exercising a large share of his options, and may be low in periods of large option grants. Columns (6) and (7) adds firm and year fixed effects. The result on normalized CEO option exercise is a bit weaker in these specifications, though the coefficient remains significant at the 10 percent level.

Taken together, the results in Tables 6 through 9 and Figures 4 and 5 suggest that managerial opportunism - as measured by the importance of pension earnings to operating earnings, the timing of merger activity and the timing of option exercises - is one determinant of the choice of assumed rates of return. That managers capitalize on inflated earnings through increased merger activity and greater exercises further suggests that other managerial decisions are impacted by the potential manipulation of pension earnings.

\section{The determinants of asset allocation decisions}

The managerial incentives we have identified may have effects not just on financial reporting and investment decisions by firms and managers but also on asset allocation decisions within pension plans. This section investigates the possibility that managers shift pension assets towards equity in order to justify a higher long-term rate of return assumptions in periods around mergers. To investigate this possibility, we use the sample that can be merged with DB pension equity allocation data. This sample, as described in section 3, contains 3,202 firm-year observations. Our empirical approach is to fit two stage least squares regressions of equity 
allocation share on the long-term rate of return, with the long-term rate of return instrumented with the acquisition dummy variable used in the previous section. ${ }^{21}$

The first two columns of Table 10 show the results of an OLS regression of equity shares on the assumed long-term rate of return. In the first column, for each percentage point higher the long-term rate of return assumption is, the percentage of the pension fund allocated to equity is 6 percentage points higher. The second column adds a full set of industry-by-year controls and this effect becomes 4.5 percentage points. There are a number of potential reasons we might observe a correlation between these two variables. One is that mangers increase the allocation of risky assets in their pension funds to justify increases long-term rates of return, but there are several alternatives. It might be the case that the long-term rate of return assumption responds to shorter term increases in the actual rate of return on pension assets, a variety of excessive extrapolation (see Benartzi (2001)). Alternatively, pension plans with higher equity allocations might have higher assumed rates given greater exposure to assets that earn risk premia.

In the third and fourth columns we attempt to address these endogeneity concerns by estimating the relationship between the equity allocation and the long-term rate of return using instrumental variables. We estimate the system of equations below:

(5') Equity allocation ${ }_{i, t}=a_{0}+a_{1}{ }^{*} \log$ Pension Sensitivity ${ }_{i, t}+a_{2} *$ Assumed $^{2} O R_{i, t}+X_{i, t}{ }^{\prime} \Gamma+\varepsilon_{i, t}$

(5") Assumed $\operatorname{ROR}_{i, t}=\beta_{0}+\beta_{1} * \log$ Pension Sensitivity ${ }_{i, t}+\beta_{2} *$ Acquiror Dummy $_{i, t}$ $+\beta_{3} *\left(\right.$ Log Pension Sensitivity ${ }_{i, t} *$ Acquiror Dummy $\left.{ }_{i, t}\right)+X_{i, t}{ }^{\prime} \Lambda+v_{i, t}$ by two-stage least squares. The first stage equation (5") is analogous to specifications in the first through third columns of Table 7, although we are now focusing on the smaller asset allocation sample. The terms represented by the matrix $X$ are included in the fourth column specification only and represent industry-by-year controls. ${ }^{22}$

\footnotetext{
${ }^{21}$ We have also explored using CEO option exercise as an instrument for the long-term rate of return assumption. The joint requirement of Compustat Executive Compensation data and data on the equity share in pension assets leads to a sample size of about 1,500 , and results using this smaller sample are not statistically significant. A similar situation arises when we use the controls for actual 12-month past pension returns used in Table 8 as controls. The results are robust when dummies are included for the missing observations, but the tests do not have sufficient statistical power when the number of sample observations is reduced by this magnitude.

${ }^{22}$ Due to the fact that our equity allocation data is compiled from two separate sources which each have different samples over different time periods, we do not move to the full firm-fixed effects specification.
} 
The identifying assumption behind this specification is that the merger decision affects equity shares in the pension fund only through its effect on the assumed long-term rate of return. Instrumenting in this manner provides a much larger effect of the long-term rate of return on the equity share. The specification in column 3 suggests that one percentage point difference in the assumed long-term rate of return (such as from $8.00 \%$ at the $25^{\text {th }}$ percentile to $9.00 \%$ at the $75^{\text {th }}$ percentile) is associated with an increase of 28 percentage points in the equity allocation. The inclusion of industry-year effects only modestly reduces this effect to a 20 percentage point increase in response to a one percentage point increase in assumed returns. While these magnitudes seem large, it useful to remember that most one-time changes in assumed rates are considerably more modest than a one percentage point change. As such, it is useful to scale these effects for modest assumed rate of return changes and view them as associating 25 basis point changes in assumed rates with five percentage point changes in equity allocation.

\section{Managerial Opportunism and Shareholder Interests}

Our results on earnings manipulation and pension decision-making illustrate how managerial actions can redistribute value between current shareholders, managers and potential shareholders. If managers are inflating profits and stock prices and then acquiring other firms with inflated stock, then current shareholders could benefit from this opportunism as value is redistributed to them from future shareholders. This would be consistent with the view of optimal incentive contracts of Bolton, Scheinkman, and Xiong (2003) and the view of stockfinanced mergers in Shleifer and Vishny (2003). ${ }^{23}$ If, instead, managers are inflating profits to enable empire-building and self-enrichment through option exercises, then value is likely being transferred from current shareholders toward managers. This view would be consistent with the managerial power view of Bebchuk, Fried and Walker (2002) and others. ${ }^{24}$

We frame our discussion of managerial opportunism and pension decision-making within this debate by investigating the relationship between assumed rates of return and the corporate

\footnotetext{
${ }^{23}$ An earlier literature similarly suggested that managerial manipulation of earnings can benefit current shareholders. In Stein $(1988,1989)$, myopic managerial actions arise in markets that are rational but imperfectly informed. Managers, averse to even temporarily undervalued equity, inflate reported earnings, and the market's conjectured relationship between reported and true earnings holds in equilibrium. Shleifer and Vishny (1990) similarly suggest that costly arbitrage can also lead to a short-term bias in the absence of an agency problem.

${ }^{24}$ For example, Yermack (1997) and Bertrand and Mullainathan (2001) note that various aspects of compensation arrangements do not correspond purely to incentive purposes, suggesting that managers use incentive compensation to extract these rents.
} 
governance environment of the firm. Specifically, we expect that if current shareholders are the beneficiaries of managerial opportunism in setting pension return assumptions, then high assumptions will be more prevalent in firms where managers are more constrained to behave in the interest of shareholders. Alternatively, if firms where managers are least constrained by shareholder interests indulge in aggressive assumed rates of return, this would be more supportive of the rent-extraction view.

Figure 6 provides evidence that long-term rate of return assumptions on pension assets are substantially higher at firms where current shareholders have weaker control over managers. Firm-year observations are sorted on the basis of the nearest preceding measure of the Gompers, Ishii, and Metrick (2003) corporate governance index. This index aggregates 24 different dummy variables representing mechanisms that firms can employ to insulate managers from shareholders. These include devices like staggered board elections, which impose delays on any contestant seeking to take over board seats. We aggregate observations into categories ranging from 1 , those where shareholders have the most control over mangers, to 6, those where managers are the most insulated from shareholders. There is a substantial increase in long-term rates of return as managers become more insulated from current shareholders. At the most democratic firms, assumed long-term rates of return are below 8.5 percent, while at the most dictatorial, they are above 9 percent. While the analysis of Figure 6 is only suggestive, it does indicate that managerial opportunism in pension decision-making does not appear to be guided by shareholder interests.

Finally, it is useful to consider the potential magnitude of these redistributive effects for a specific example. We return to IBM to consider the effects of the inflated stock prices arising from inflated pension earnings. Specifically, we attempt to outline the scale of managerial enrichment during that period due to pension decision-making. While this exercise is necessarily speculative, it is useful for scaling the potential redistribution in this instance. The first panel of Table 12 provides information on IBM market values and acquisition activity from 1997 to 2001, the period emphasized in Table 1. This period saw an increase in market value of almost $\$ 100$ billion as well as robust acquisition activity. IBM made 41 acquisitions during this period valued at over $\$ 4$ billion. The second panel combines the estimates from Table 1 regarding the effect of the deviations from an assumed rate of return of $9.25 \%$ on income with the Coronado and Sharpe (2003) estimates suggesting that pension earnings are capitalized in the same manner as 
operating earnings. This assumption gives an estimated stock price in the absence of those deviations from the $9.25 \%$ long-term rate of return assumption. Finally, Gerstner's option exercise activity is employed to arrive at an estimate of the dollar value garnered by Gerstner that arose from the deviations from the $9.25 \%$ rate. This estimate totals more than $\$ 12$ million for the period.

How reliable is this $\$ 12$ million estimate? Obviously, it relies on numerous assumptions - several of which may be construed to be conservative or aggressive. The most aggressive assumption is the one borrowed from Coronado and Sharpe (2003) - that markets completely fail to distinguish between pension and operating earnings and capitalize them similarly. Having said that, the estimate may be quite conservative, particularly if one believes that the reduced growth rates in the absence of the changed assumptions would have changed the capitalization rate of all earnings. If this were the case even to a limited degree, the scope of managerial enrichment resulting from the changed assumptions would be substantially larger. Specifically, the final column considers an alternative scenario where the capitalization rate of all earnings is altered by the changed growth rates noted in introduction. ${ }^{25}$ Under these assumptions, this estimate rises to nearly $\$ 76$ million. $^{26}$

If between \$12 million and \$76 million from these changed assumptions were directed to the CEO, where did it come from? This discussion of the gainers and losers from the higher pension return assumption necessarily even more conjectural. Given the overall scope of market value gains experienced by IBM shareholders during this period, the amount may be trivial and may have resulted from an optimal compensation arrangement. Indeed, if merger activity financed by stock or employee ownership was enabled by these assumptions, preexisting shareholders may be the beneficiaries of value transfers from these new shareholders. ${ }^{27}$ Our reading of their 10 -Ks suggest that approximately $25 \%$ of the $\$ 4$ billion of target value was financed through share issuance. Given that over $\$ 10$ billion of market capitalization by the end

\footnotetext{
${ }^{25}$ The calculations on the changed capitalization rates require a discount rate and two alternative growth rates. For these purposes, we use a $12 \%$ discount rate and the difference in multiples, using a growing perpetuity formula, arising from a growth rate changing from $6.7 \%$ to $5.6 \%$. Such a calculation is necessarily conjectural but does provide a useful alternative to the baseline assumption of no changed capitalization effect.

${ }^{26}$ It is useful to frame these figures in the context of Gerstner's overall compensation during the period from 1997 to 2001. Execucomp data indicates that Gerstner received \$45 million in cash compensation and \$366 in total compensation, including option exercises, during that period.

${ }^{27}$ IBM 10-Ks are somewhat unclear on the financing of each transaction making it somewhat problematic to determine the precise degree to which IBM issued shares to finance their acquisitions.
} 
of 2001 is calculated to reflect capitalized pension earnings arising from these increases, it does not appear that a substantial fraction was value transfers accomplished through mergers. Finally, it is possible that these rate of return changes and resulting incremental compensation was facilitated to enable exercises of options and transfers of value away from current shareholders and toward management. Obviously, it is impossible to distinguish with certainty between these alternatives. Subsequent to Gerstner's departure, the assumed rate of return was revised downward to 9.5\% in 2002 and IBM's market value fell by $\$ 70$ billion during 2002 to return to 1998 levels. These coincident changes, while tantalizing, were undoubtedly related to many other factors in the capital markets and IBM's competitive environment.

\section{Conclusion}

In a setting where managers have considerable discretion and where manipulated earnings are capitalized into stock prices, managers appear to exploit their discretion and alter investment decisions to justify and capitalize on manipulated earnings. The latitude managers enjoy in pension accounting and the inability of the market to fully distinguish between inflated pension earnings and operating earnings combine to provide managers with a powerful incentive to opportunistically characterize pension assets. Managers facing large incentives to manipulate earnings through pension decisions - either because of the sensitivity of firm earnings to changed assumptions, impending merger activity, or large incentive compensation contracts appear to alter their assumed returns significantly in response to these incentives. The evidence on merger activity and option exercises confirms the role of earnings manipulation but also makes clear that reporting distortions induced by managerial motivations can alter manager and firm investment decisions. Furthermore, rationalizing these higher assumed returns is easier in the context of higher equity allocations and our IV analysis indicates that higher assumed returns are, in fact, associated with higher equity allocations.

Previous studies of managerial opportunism and earnings manipulation have emphasized large indiscretions in small samples, as in Erikson et. al. (2003) on earnings fraud, or on more aggregated measures of misreporting through accrual accounting, as in Bergstresser and Philippon (2003). In this paper, we emphasize a simple, transparent but influential reporting decision that in a large sample appears to be used opportunistically. In addition, we show that 
this opportunism has further effects in enabling merger activity and option exercises and in determining asset allocation within those plans.

To the degree that pension earnings are capitalized into market prices, the opportunistic use of assumed rates of return may lead to aggregate levels of overvaluation, as suggested by Coronado and Sharpe (2003). Our results on asset allocation add another mechanism by which pension accounting could have contributed to market overvaluation as increased assumed rates also appear to be associated with higher equity allocations. While market participants were capitalizing pension earnings, firms were increasing equity exposures to justify those very pension earnings. 


\section{References}

Amir, E. and S. Benartzi, 1998. "The expected rate of return on pension funds and asset allocation as predictors of portfolio performance,” Accounting Review 73 (3), 335-352.

Bebchuck, L. A., J. M. Fried, and D. I. Walker, 2002. "Managerial power and rent extraction in the design of executive compensation,” University of Chicago Law Review 69 (3), 751846.

Benartzi, S., 2001. "Excessive extrapolation and the allocation of 401(k) accounts to company stock,” Journal of Finance 56 (5), 1747-1764.

Bergstresser, D. and T. Philippon, 2003. “CEO incentives and earnings management: evidence from the 1990s,” mimeo, Harvard Business School.

Bertrand, M. and S. Mullainathan, 2001. “Are CEO’s rewarded for luck? The ones without principals are,” Quarterly Journal of Economics 116 (3), 901-932.

Bodie, Z., J. Light, R. Mørck and R.Taggart, 1985. “Corporate pension policy: An empirical investigation,” Financial Analysts Journal 41 (5), 10-16.

Bolton, P., J. Scheinkman, and W. Xiong, 2003. "Executive compensation and short-termist behavior in speculative markets,” Princeton University Working Paper.

Chan, K., L. Chan, N. Jegadeesh, and J. Lakonishok, 2001. "Earnings quality and stock returns,” NBER working paper \#8308.

Coronado, J. and S. Sharpe, 2003. “Did pension plan accounting contribute to a stock market bubble,” mimeo, Board of Governors of Federal Reserve System.

Erickson, M., M. Hanlon, and E. Maydew, 2003. "How much are nonexistent earnings worth?” mimeo, University of North Carolina.

Fama, E. F. and K. R. French, 2003. “Financing decisions: who issues stock?,” University of Chicago Working Paper.

Feldstein, M. and R. Mørck, 1983. "Pension funding decisions, interest rate assumptions and share prices,” Financial Aspects of the U.S. Pension System, eds. Z. Bodie and J. Shoven. Chicago: University of Chicago Press (1984), 177-210.

Feldstein, M. and S. Seligman, 1981. "Pension Funding, Share Prices, and National Savings.” Journal of Finance 36 (4): 801-24.

Frank, M., 2002. "The impact of taxes on corporate defined benefit pension plan asset allocation,” Journal of Accounting Research 40 (4), 1163-1190.

Franzoni, F. and J. M. Marin, 2003. "Pension Plan Funding and Stock Market Efficiency,” Working Paper, HEC School of Management. 
Friedman, B., 1983. "Pension funding, pension asset allocation, and corporate finance: Evidence from individual company data," Financial Aspects of the U.S. Pension System, eds. Z. Bodie and J. Shoven. Chicago: University of Chicago Press (1984), 107-147.

Gold, J. 2003, “Accounting/actuarial biases enable equity investment by defined benefit pension plans,” Working Paper, University of Pennsylvania.

Gompers, P., Ishii, J., and A. Metrick, 2003. “Corporate governance and equity prices,” The Quarterly Journal of Economics 118 (1), 107-155.

Hall, B. and K. Murphy, 2003. "The trouble with executive stock options," The Journal of Economic Perspectives 17 (3), 49-70.

Hawkins, D., 2001. “Retiree Benefits,” Harvard Business School case 9-197-021.

Healy, P. and J. Wahlen, 1999. "A review of the earnings management literature and its implications for standard setting,” Accounting Horizons 13 (4), 365-383.

Langbein, J.H. and B.A. Wolk, 2000. Pension and Employee Benefit Law, $3^{\text {rd }}$ ed. New York, NY: Foundation Press.

Maclean, B., 2002. “That old financial magic,” Fortune, February 18, 2002.

Obinata, T., 2000, "Choice of pension discount rate in financial accounting and stock prices," mimeo, University of Tokyo.

Papke, L., 1992. Trends in Pensions. eds., John Turner and Daniel Beller, Department of Labor Pension and Welfare Benefits Administration.

Rauh, J., 2003. "Investment and financing constraints: evidence from the funding of corporate pension plans," mimeo, Massachusetts Institute of Technology.

Shleifer, A. and R. W. Vishny, 2003. "Stock market driven acquisitions," Journal of Financial Economics 70 (3), 295-311.

Shleifer, A. and R. W. Vishny. 1990. "Equilibrium short horizons of investors and firms," American Economic Review 80 (2), 148-153.

Sloan, R.G., 1996. "Do stock prices fully reflect information in accruals and cash flows about future earnings?” Accounting Review 71 (3), 89-315.

Stein, J. 1988. “Takeover threats and managerial myopia,” Journal of Political Economy 96 (1), 61-80.

Stein, J. 1989. "Efficient firm and inefficient markets," Quarterly Journal of Economics 104 (4), 655-669. 
Teoh, S.H., I Welch, and T.J. Wong, 1998a. "Earnings management and the post-issue performance of seasoned equity offerings," Journal of Financial Economics 50 (1), 6399.

Teoh, S.H., I. Welch, and T.J. Wong, 1998b. “Earnings management and the long-term market performance of initial public offerings,” Journal of Finance 53 (6), 1935-1974.

Welch, I. 2001. “The equity premium consensus forecast revisited,” Cowles Foundation discussion paper 1325. Journal of Business, forthcoming.

Xie, H., 2001. “The mispricing of abnormal accruals,” Accounting Review 76 (3), 357-373.

Yermack, D. 1997. "Good Timing: CEO stock option awards and company news announcements,” Journal of Finance 52 (2), 449-476.

Zion, D. and B. Carcache, 2002. The Magic of Pension Accounting. Credit Suisse First Boston. 
Figure 1: End-of-Year Pension Funding Status 1991-2002

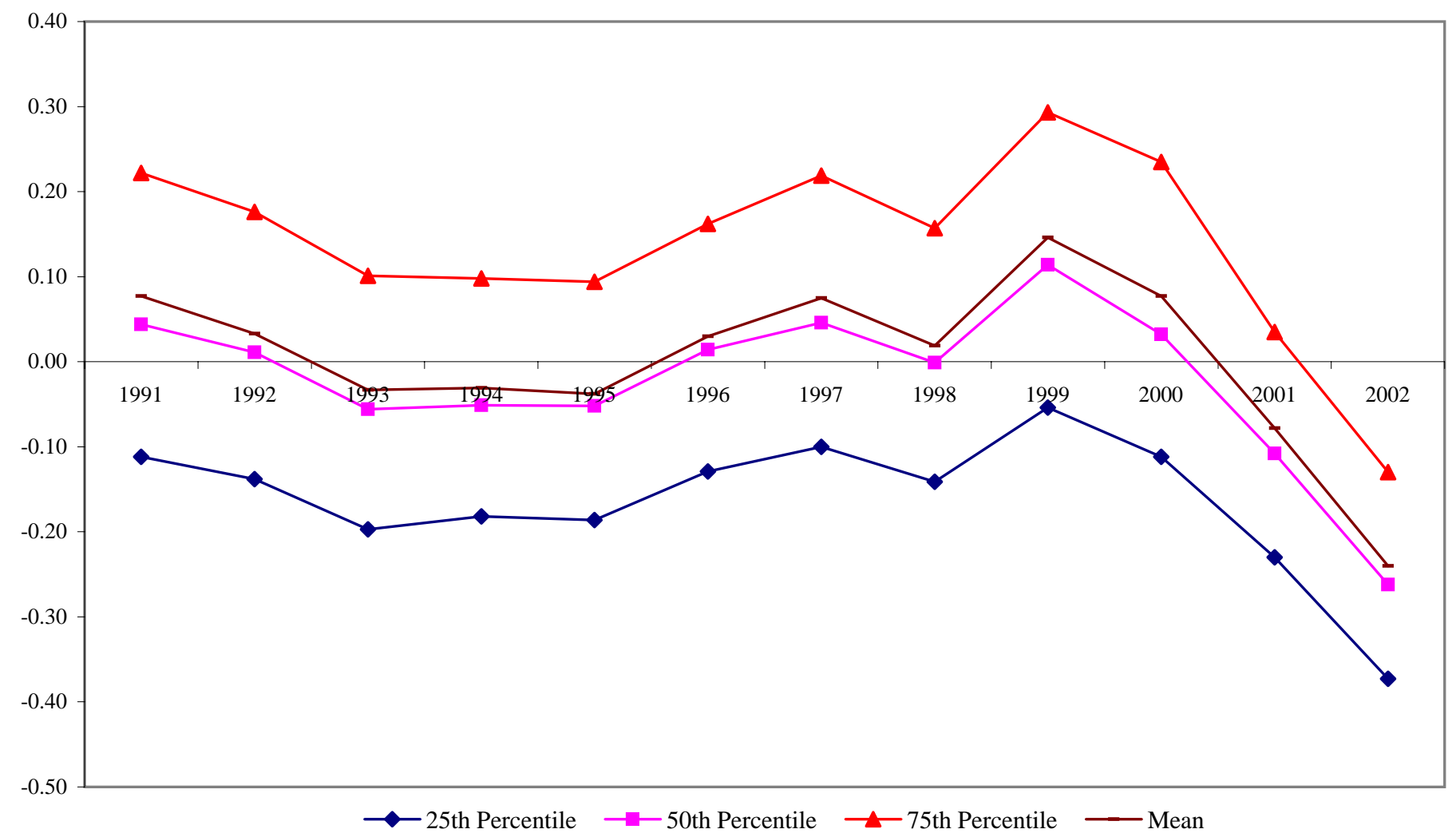

Note. Funding status is the ratio of the difference of Pension Assets and Pension Projected Benefit Obligation to Pension Projected Benefit Obligation. The sample is firms in Compustat that report LTROR, pension asset size, and positive operating income

\section{Figure 2: Mean Share of Pension Fund Assets Invested in Equity}

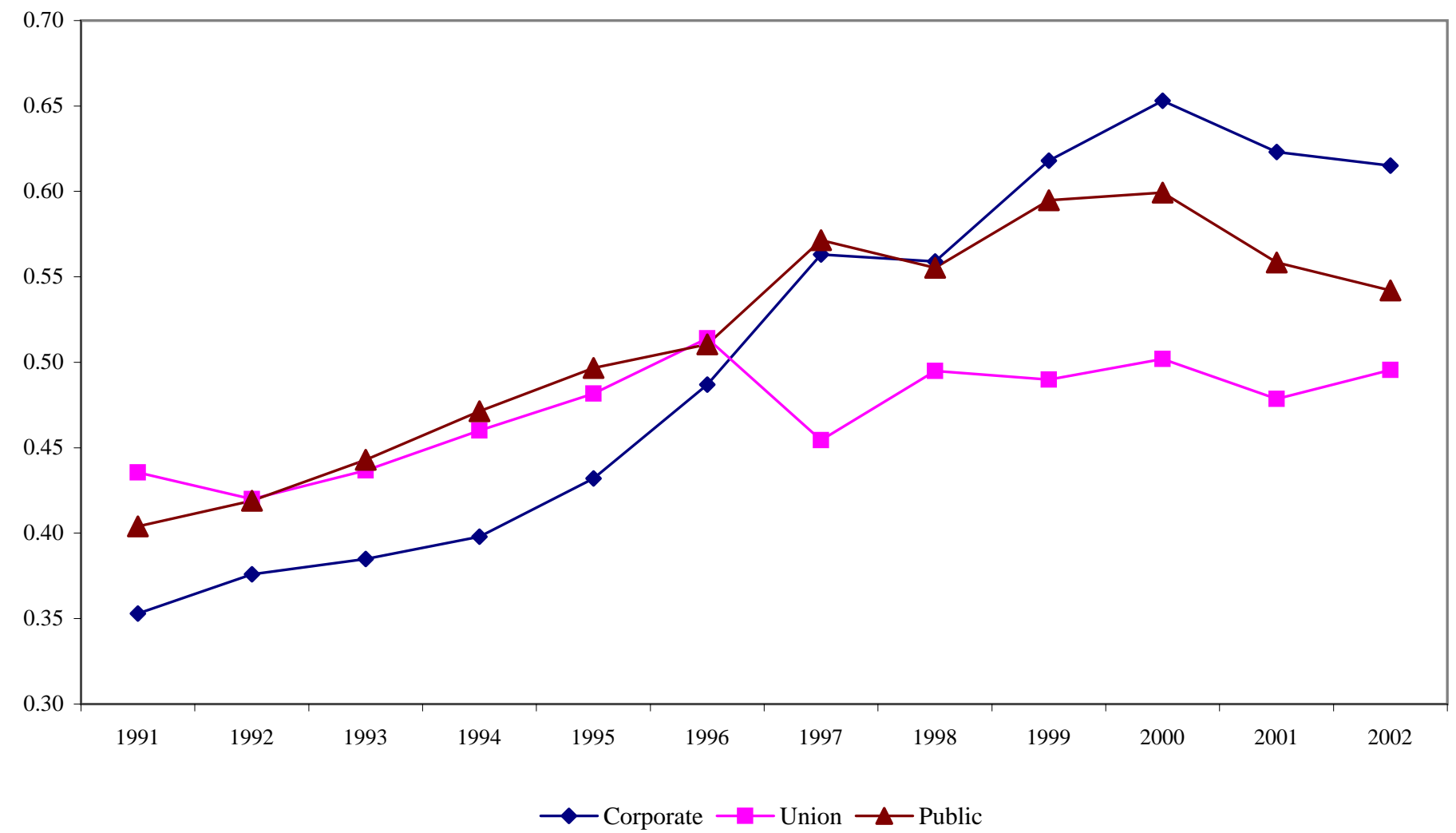

Note. Corporate data from Pensions and Investments and IRS 5500 filings. Union and public data from Pensions and Investments. Equity includes domestic, international, and own-company equity; excludes investments in private equity. 
Figure 3: Long Term Rate of Return Assumptions and Implied Equity Returns

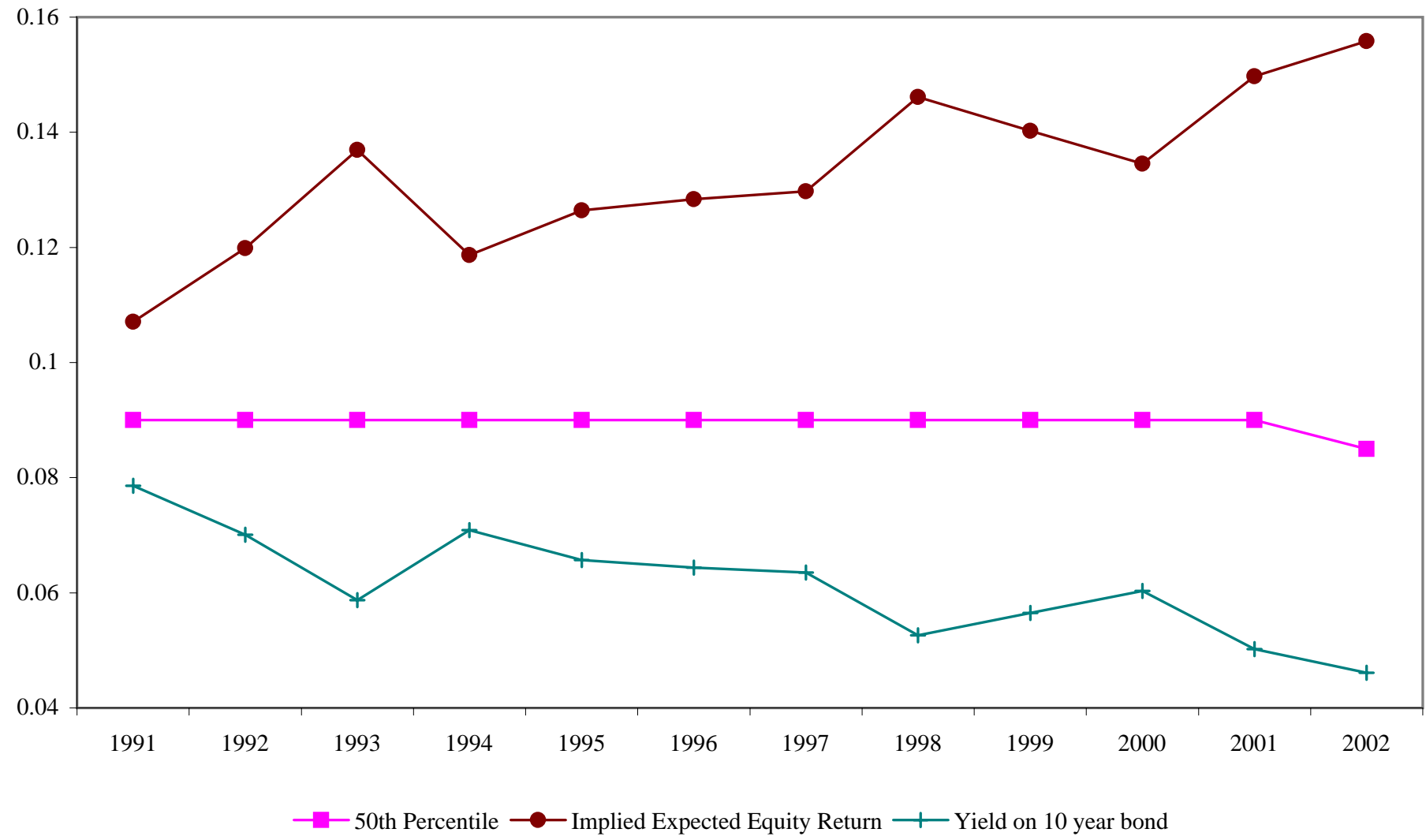

Note. The median long-term rate of return assumption is taken from the sample of firms from Compustat. Yields on 10-year bond from Federal Reserve. The implied expected equity return is the expected return on equities given a portfolio of $40 \%$ equity and $60 \%$ bonds with prevailing bond yields and a $9 \%$ assumed return on the portfolio.

Figure 4: Long-Term Rate of Return Assumption Around Mergers, All Firms

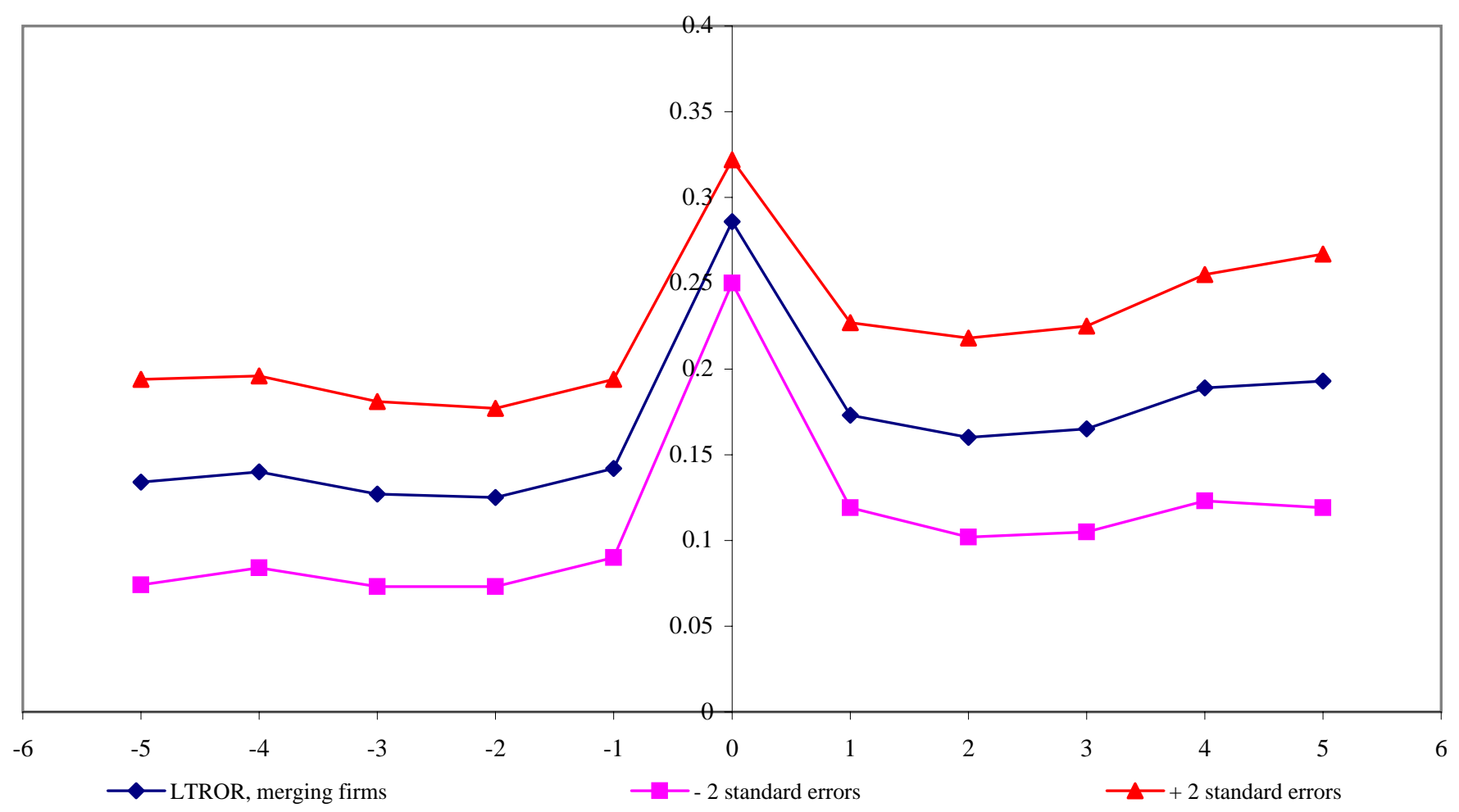

Note. Figure shows long-term rate of return assumptions reported by firms in periods around mergers. These averages are regression-adjusted for calendar-year effects. The estimate for period 0 is the average assumption for firms reporting acquisitions of another firm in that year. The estimate for period 1 is the average assumption for firms reporting acquisition of another firm in previous year, but not current year. The estimate for period - 1 is the average LTROR assumption for firms reporting acquisitions of another firm in next year, but not current year. Long-term rate of return assumption data from Compustat. 
Figure 5: Long-Term Rate of Return Assumptions around CEO option exercise, All Firms

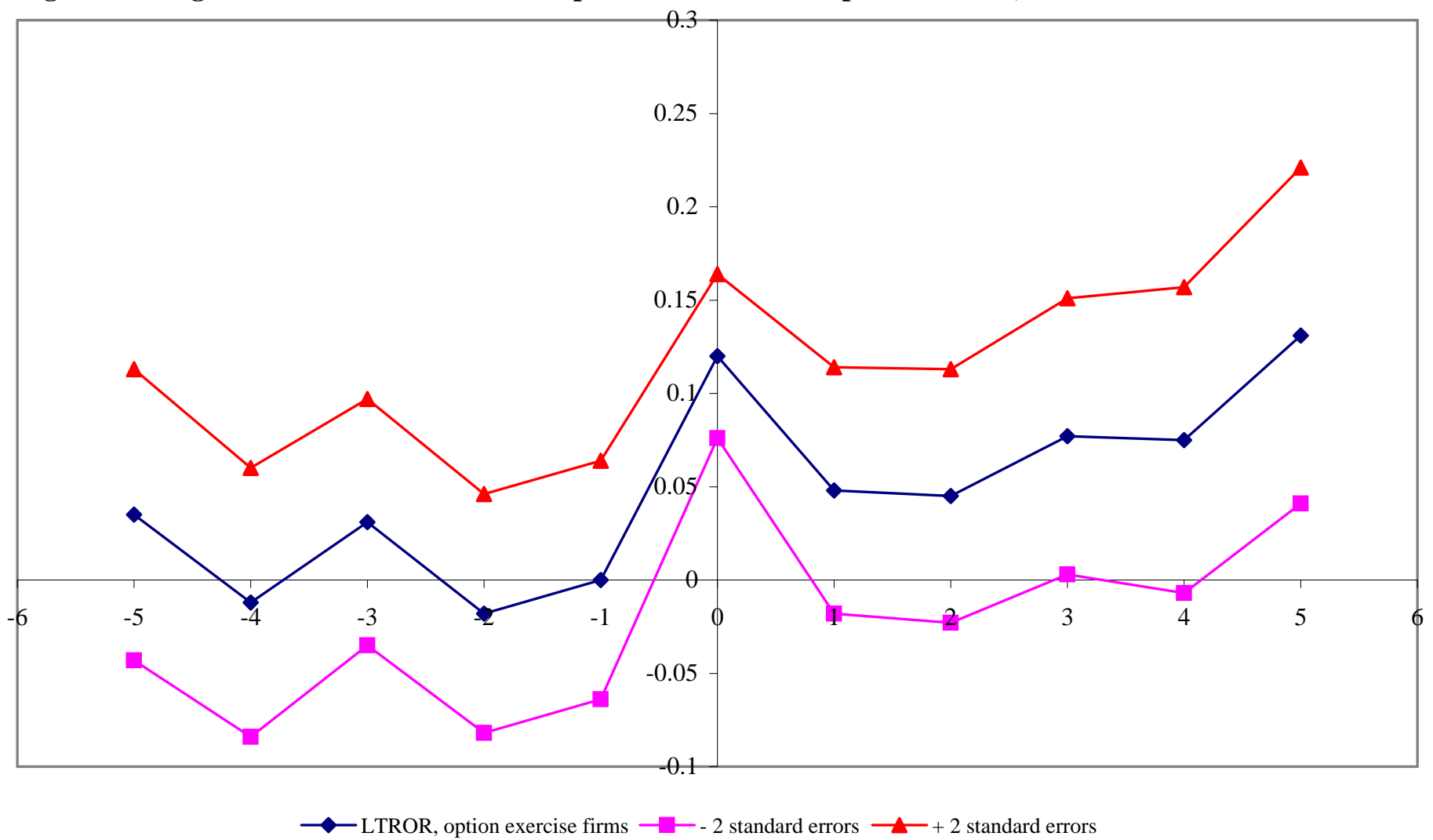

Note. Figure shows long-term rate of return assumptions reported by firms in periods around CEO option exercise. These averages are regression-adjusted for calendar year effects. At period 0 is average assumption for firms whose CEOs report option exercise in that year. At period 1 is average assumption for firms whose CEOs exercise options in previous year, but not current year. At period -1 is average LTROR assumption for firms whose CEOs exercise options in next year, but not current year. Long-term rate of return assumption data from Compustat.

Figure 6: Rate of Return Assumptions by Quality of Corporate Governance

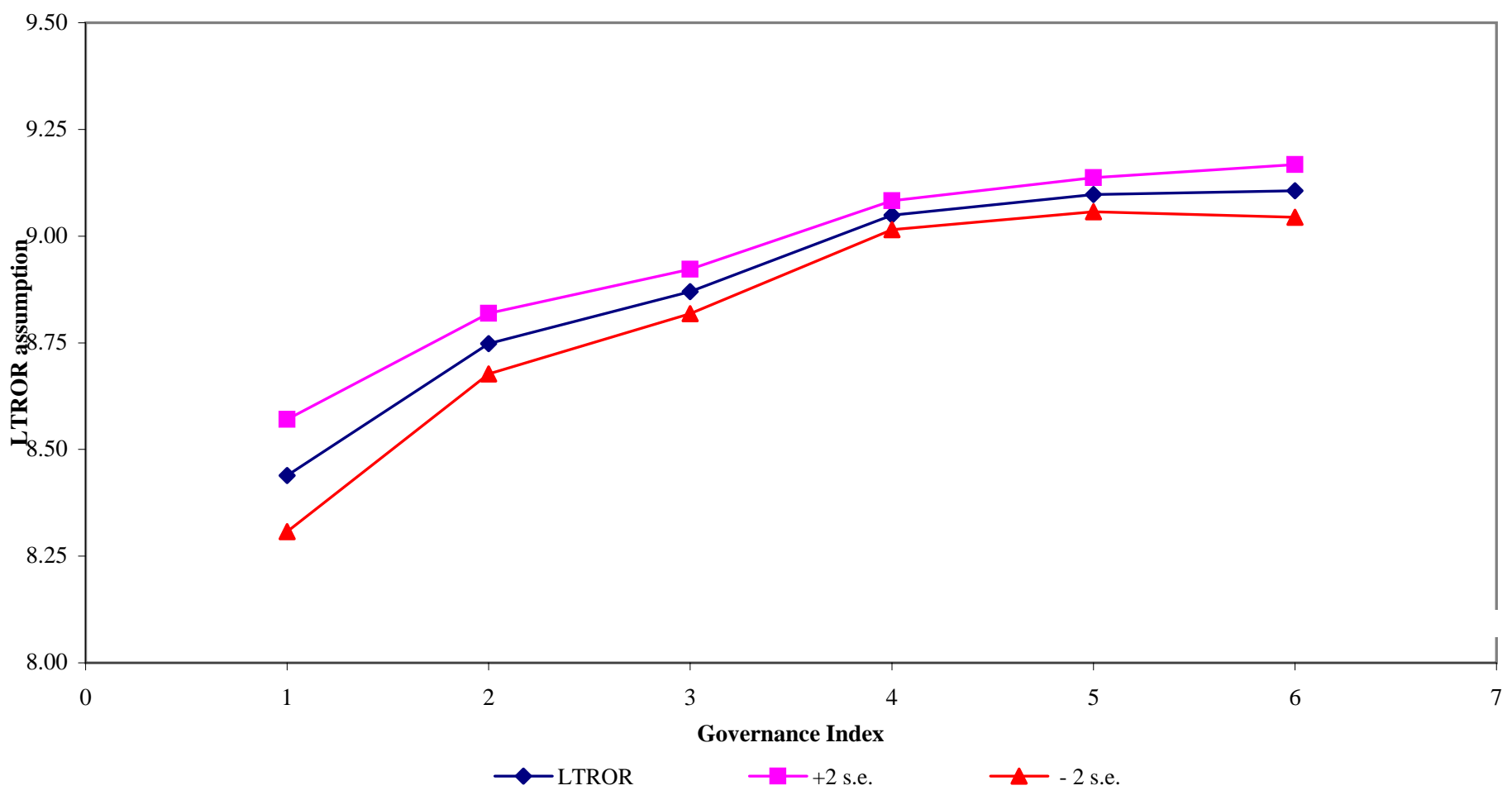

Note. Figure shows long-term rate of return assumptions plotted against a corporate governance index based on Gompers, Ishii and Metrick (2003). The best governed firms (group 1) scored 1-5 on the G-I-M index, group 2 scored 6-7, group 3 scored 8-9, group 4 scored 10-11, group 5 scored 12-13, and the words governed firms (group 6) scored 14 or above. Long-term rate of return assumption data from Compustat. 
Table 1: Pension Decision Making at IBM, 1993-2001

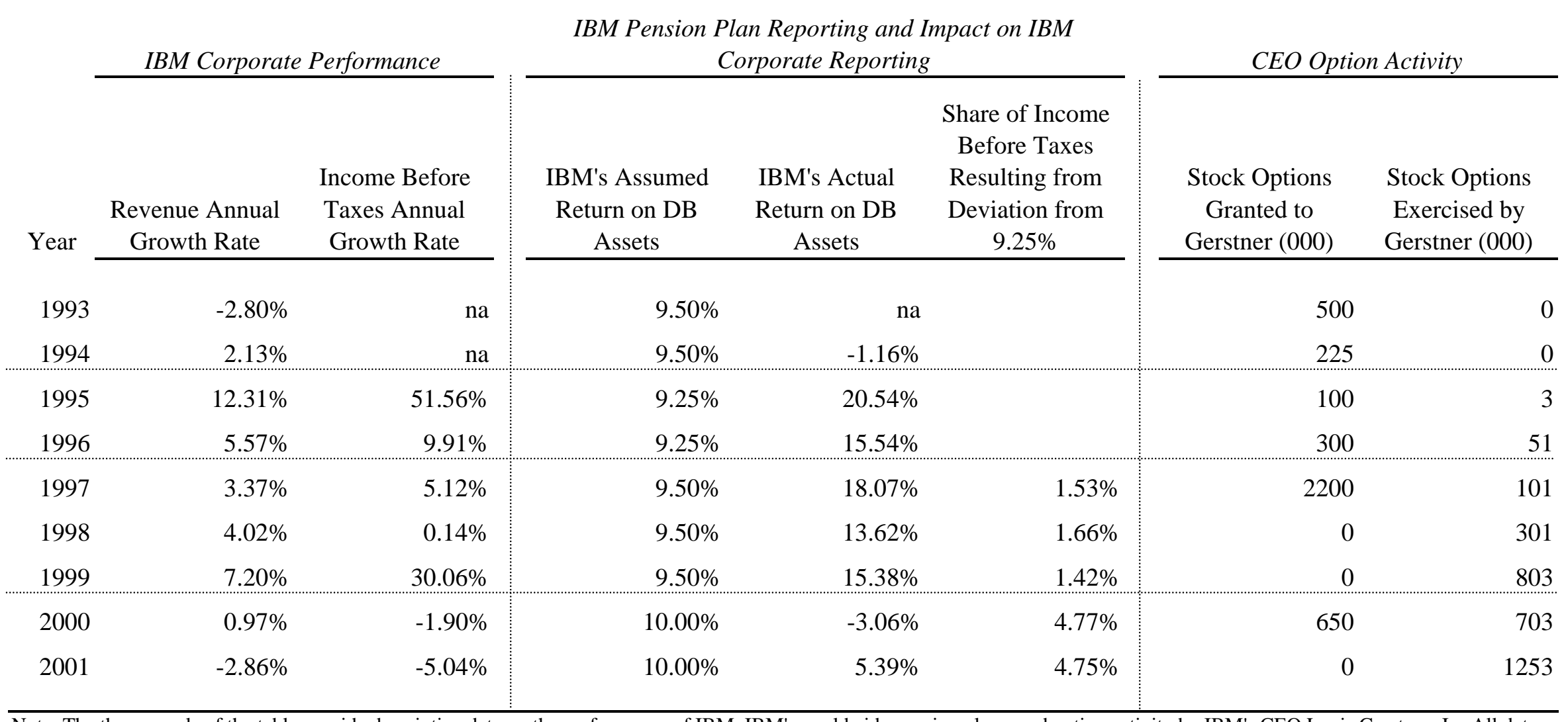

Note: The three panels of the table provide descriptive data on the performance of IBM, IBM's worldwide pension plans, and option activity by IBM's CEO Louis Gerstner, Jr. All data on IBM corporate performance and pension plan accounting are calculated from data from 10-K filings, and data on option activity are taken from the Compustat Executive

Compensation database. Reported earnings are affected by the rate of return assumption because assumed returns on pension plan assets can be deducted from costs, with differences between assumed and actual returns amortized over long periods. The "Share of Income Before Taxes Resulting from Deviation from 9.25\%" is the product of the difference between annual assumed rates and $9.25 \%$ and worldwide pension assets, divided by annual income before taxes. 
Table 2: The Contribution of Assumed Pension Asset Returns to Operating Income, by Rate of Return Assumptions and Pension Sensitivities.

\begin{tabular}{|c|c|c|c|c|c|c|c|c|c|c|}
\hline \multicolumn{2}{|c|}{ Pension sensitivity } & percentile & $5^{\text {th }}$ & $10^{\text {th }}$ & $25^{\text {th }}$ & Mean & $50^{\text {th }}$ & $75^{\text {th }}$ & $90^{\text {th }}$ & $95^{\text {th }}$ \\
\hline & & level & 0.013 & 0.058 & 0.112 & 0.299 & 0.716 & 1.494 & 3.042 & 5.150 \\
\hline \multirow[b]{2}{*}{ Long-term } & & $\log$ & -4.370 & -2.847 & -2.193 & -1.209 & -0.334 & 0.401 & 1.113 & 1.639 \\
\hline & percen & & & & & & & & & \\
\hline \multirow{8}{*}{$\begin{array}{l}\text { rate of } \\
\text { return } \\
\text { assumption } \\
\text { (LTROR) }\end{array}$} & $5^{\text {th }}$ & 7.00 & 0.089 & 0.406 & 0.781 & 2.090 & 5.013 & 10.458 & 21.294 & 36.050 \\
\hline & $10^{\text {th }}$ & 7.50 & 0.095 & 0.435 & 0.837 & 2.240 & 5.372 & 11.205 & 22.815 & 38.625 \\
\hline & $25^{\text {th }}$ & 8.00 & 0.101 & 0.464 & 0.893 & 2.389 & 5.730 & 11.952 & 24.336 & 41.200 \\
\hline & Mean & 8.61 & 0.109 & 0.499 & 0.961 & 2.571 & 6.166 & 12.863 & 26.192 & 44.342 \\
\hline & $50^{\text {th }}$ & 9.00 & 0.114 & 0.522 & 1.004 & 2.687 & 6.446 & 13.446 & 27.378 & 46.350 \\
\hline & $75^{\text {th }}$ & 9.40 & 0.119 & 0.545 & 1.049 & 2.807 & 6.732 & 14.044 & 28.595 & 48.410 \\
\hline & $90^{\text {th }}$ & 10.00 & 0.127 & 0.580 & 1.116 & 2.986 & 7.162 & 14.940 & 30.420 & 51.500 \\
\hline & $95^{\text {th }}$ & 10.00 & 0.127 & 0.580 & 1.116 & 2.986 & 7.162 & 14.940 & 30.420 & 51.500 \\
\hline
\end{tabular}

Note: The table provides the percentage of operating income attributable to assumed returns on pension assets, by pension sensitivity and assumed long term rate of return assumptions. Pension sensitivity is the ratio of pension assets to operating income. The distribution provided across columns corresponds to the sample used in the analysis. The long term rate of return assumption is the assumed rate of return on pension assets in corporate financial reports and the distribution provided along the rows corresponds to the sample used in the analysis. Reporter earnings are affected by the rate of return assumption because assumed returns on pension plan assets can be deducted from costs, with differences between assumed and actual returns amortized over long periods. 
Table 3: The Magnitude of Pension Assets, 1991-2002

\begin{tabular}{|c|c|c|c|c|c|c|c|c|}
\hline \multirow[b]{2}{*}{ Year } & \multirow{2}{*}{$\begin{array}{c}\text { Sample } \\
\text { Count }\end{array}$} & \multirow{2}{*}{$\begin{array}{c}\text { Balance Sheet } \\
\text { Assets of } \\
\text { Firms } \\
\text { in (2) (\$bn) } \\
\end{array}$} & \multirow{2}{*}{$\begin{array}{c}\text { Pension } \\
\text { Assets of } \\
\text { Firms } \\
\text { in (2) (\$bn) } \\
\end{array}$} & \multirow{2}{*}{$\begin{array}{c}\text { DB Pension } \\
\text { Assets / } \\
\text { Total Assets } \\
\end{array}$} & \multicolumn{4}{|c|}{ DB Pension Assets (\$m) } \\
\hline & & & & & Mean & 25th Percentile & Median & 75th Percentile \\
\hline$(1)$ & $(2)$ & $(3)$ & $(4)$ & $(5)$ & $(6)$ & $(7)$ & $(8)$ & $(9)$ \\
\hline 1991 & 1645 & $7,061.80$ & 735.1 & $10.41 \%$ & 446.9 & 10.2 & 46.5 & 210.1 \\
\hline 1992 & 1725 & $7,723.50$ & 764.9 & $9.90 \%$ & 443.4 & 10.7 & 46.7 & 211.4 \\
\hline 1993 & 1755 & $8,770.60$ & 879.2 & $10.02 \%$ & 501.0 & 10.9 & 50.4 & 236.3 \\
\hline 1994 & 1779 & $9,798.70$ & 830.6 & $8.48 \%$ & 466.9 & 10.6 & 48.7 & 218.5 \\
\hline 1995 & 1741 & $10,189.70$ & 962.7 & $9.45 \%$ & 552.9 & 11.6 & 53.5 & 247.9 \\
\hline 1996 & 1704 & $10,603.20$ & $1,034.30$ & $9.75 \%$ & 607.0 & 13.3 & 63.1 & 283.4 \\
\hline 1997 & 1630 & $11,214.60$ & $1,156.20$ & $10.31 \%$ & 709.4 & 16.6 & 76.6 & 331.8 \\
\hline 1998 & 1589 & $12,492.80$ & $1,276.60$ & $10.22 \%$ & 803.4 & 17.4 & 86.0 & 414.6 \\
\hline 1999 & 1544 & $14,319.00$ & $1,404.40$ & $9.81 \%$ & 909.6 & 19.7 & 101.1 & 454.0 \\
\hline 2000 & 1453 & $14,739.10$ & $1,413.50$ & $9.59 \%$ & 972.8 & 20.0 & 100 & 482.3 \\
\hline 2001 & 1258 & $14,957.50$ & $1,067.50$ & $7.14 \%$ & 848.6 & 21.5 & 94.9 & 443.5 \\
\hline 2002 & 1502 & $19,249.60$ & $1,093.60$ & $5.68 \%$ & 728.1 & 14.9 & 68.2 & 333.6 \\
\hline
\end{tabular}

Note: The table characterizes the magnitude of firm operating and pension assets for firms in Compustat that report long term rates of return, pension asset size, and positive operating income. The data are from Compustat. 
Table 4: Changes in Long-Term Rate of Return Assumptions (1992-2002)

\begin{tabular}{|c|c|c|c|c|c|}
\hline $\begin{array}{c}\text { Year } \\
(1)\end{array}$ & $\begin{array}{c}\text { Mean } \\
\text { Change } \\
(2)\end{array}$ & $\begin{array}{c}\text { Number } \\
\text { of Increases } \\
\text { (3) }\end{array}$ & $\begin{array}{l}\text { Number } \\
\text { No Change } \\
\text { (4) }\end{array}$ & $\begin{array}{c}\text { Number } \\
\text { of Decreases } \\
(5)\end{array}$ & $\begin{array}{l}\text { Total } \\
\text { Count } \\
(6)\end{array}$ \\
\hline 1992 & -0.05 & 90 & 1288 & 198 & 1576 \\
\hline 1993 & -0.15 & 87 & 1161 & 358 & 1606 \\
\hline 1994 & -0.05 & 136 & 1257 & 257 & 1650 \\
\hline 1995 & 0.06 & 186 & 1277 & 140 & 1603 \\
\hline 1996 & -0.04 & 172 & 1288 & 128 & 1588 \\
\hline 1997 & 0.02 & 172 & 1239 & 112 & 1523 \\
\hline 1998 & -0.03 & 150 & 1101 & 159 & 1410 \\
\hline 1999 & 0.02 & 157 & 1079 & 140 & 1376 \\
\hline 2000 & 0.04 & 177 & 1049 & 107 & 1333 \\
\hline 2001 & -0.03 & 98 & 948 & 152 & 1198 \\
\hline 2002 & -0.31 & 42 & 591 & 508 & 1141 \\
\hline
\end{tabular}

Note: The table provides the mean change in the long term rate of return and the number of increases, non-changes and decreases for the sample of firms from Compustat that report pension asset size, positive operating income, and assumed long term rates of return in the current and previous year. 
Table 5: Summary Statistics

\begin{tabular}{|c|c|c|c|c|}
\hline Variable & Mean & Median & $\begin{array}{l}\text { Standard } \\
\text { Deviation }\end{array}$ & Observations \\
\hline Pension Assets (\$m) & 653.0 & 65.5 & 2631.2 & 19,325 \\
\hline Operating Assets (Book Value, \$m) & 7302.5 & 911.7 & 32577.9 & 19,325 \\
\hline Pension Assets / Operating Income & 4.460 & 0.716 & 226.8 & 19,325 \\
\hline Pension Assets / Operating Assets & 0.142 & 0.086 & 0.255 & 19,324 \\
\hline Pension Liabilities ( $\$ \mathrm{~m})$ & 621.3 & 67.0 & 2353.2 & 19,325 \\
\hline $\begin{array}{l}\text { Log Ratio of Annual Pension Assets to } \\
\text { Operating Income }\end{array}$ & -0.440 & -0.334 & 1.398 & 19,325 \\
\hline $\begin{array}{l}\text { Log Ratio of Average Pension Assets to } \\
\text { Operating Income }\end{array}$ & -0.446 & -0.375 & 1.357 & 19,325 \\
\hline $\begin{array}{l}\text { Log Ratio of Annual Pension Liabilities to } \\
\text { Operating Income }\end{array}$ & -0.382 & -0.322 & 1.289 & 19,263 \\
\hline Assumed long-term rate of return (\%) & 8.746 & 9.000 & 1.115 & 19,325 \\
\hline Change in long-term rate of return (\%) & -0.044 & 0.000 & 0.703 & 16,004 \\
\hline Acquirer Indicator & 0.261 & 0.000 & 0.439 & 19,325 \\
\hline CEO option exercise/Equity market value (\%) & 0.296 & 0.000 & 1.780 & 7,075 \\
\hline CEO \# options exercised/ \# Options held & 0.105 & 0.000 & 0.554 & 5,951 \\
\hline CEO \# options granted/ \# Options held & 0.264 & 0.200 & 0.346 & 5,951 \\
\hline Equity Allocation & 0.498 & 0.575 & 0.247 & 3,202 \\
\hline
\end{tabular}

Note: All data on operating performance, pension assets, and pension assumptions are drawn from Compustat for the sample of firms that report long term rates of return, pension asset size, and positive operating income. Acquisitions data are drawn from the Securities Data Company (SDC) database of mergers and acquisitions. CEO option data are drawn from the Compustat Executive Compensation database. Equity allocation data are drawn from both the Pensions and Investments Survey and IRS 5500 filings. The equitv allocation sample excludes firms with assets in opaque trusts 

(1)
(2)
(3)
(4)
(5)
(6)

(7)

Log Ratio of Annual

Pension Assets to Annual

$\begin{array}{cccccc}0.113^{* * *} & 0.072^{* * *} & 0.1099^{* * *} & 0.123 & * * * & 0.119 \\ (0.013) & (0.017) & (0.013) & (0.015) & (0.015) & 0.117 \text { *** }\end{array}$

Operating Income

Log Ratio of Average

Pension Assets to Annual

$0.114 * * *$

Operating Income

Log Ratio of Annual

Pension Liabilities to

Annual Operating Income

Time Trend

$$
-0.043 * * *
$$

Time Trend Interacted with

$0.009 * * *$

Log Ratio

(0.003)

\begin{tabular}{|c|c|c|c|c|c|c|c|c|}
\hline Industry Fixed Effects? & $\mathrm{N}$ & $\mathrm{N}$ & $\mathrm{N}$ & $\mathrm{Y}$ & $\mathrm{Y}$ & $\mathrm{N}$ & $\mathrm{N}$ & $\mathrm{N}$ \\
\hline Year Effects? & $\mathrm{N}$ & $\mathrm{N}$ & $\mathrm{Y}$ & $\mathrm{N}$ & $\mathrm{Y}$ & $\mathrm{N}$ & $\mathrm{N}$ & $\mathrm{N}$ \\
\hline Industry*Year Effects? & $\mathrm{N}$ & $\mathrm{N}$ & $\mathrm{N}$ & $\mathrm{N}$ & $\mathrm{N}$ & $\mathrm{Y}$ & $\mathrm{Y}$ & $\mathrm{Y}$ \\
\hline R-Squared & 0.02 & 0.03 & 0.04 & 0.06 & 0.07 & 0.10 & 0.09 & 0.09 \\
\hline Firms & 3,247 & 3,247 & 3,247 & 3,247 & 3,247 & 3,247 & 3,247 & 3,247 \\
\hline
\end{tabular}

Note: The dependent variable in these regressions is the assumed rate of return on pension assets. Standard errors, reported in parentheses are corrected for firm-level clustering. The sample includes firms in Compustat which report an assumed long-term rate of return on pension plan assets, pension plan asset size, and positive operating income. Data are from Compustat. ${ }^{* * *}$ indicates significance at the $1 \%$ level. 


\section{Dependent Variable: Assumed Long-Term Rate of Return on Pension}

(1)

$$
\begin{array}{cc}
0.103 & 0.103 \\
(0.015) & (0.016)
\end{array}
$$

(3)

(4)

(5)

(6)

$\begin{array}{lcc}\text { Log Ratio of Annual } & 0.103^{* * *} & 0.103^{* * *} \\ \text { Pension Assets to Annual } & (0.015) & (0.016)\end{array}$

Operating Income

Log Ratio of Average

Pension Assets to Annual

Operating Income

Log Ratio of Annual

Pension Liabilities to

Annual Operating Income

Acquirer Indicator

$0.315 * * *$

$0.338 * * *$

(0.028)

(0.029)

$0.337 * * *$

(0.029)

$0.060 * * *$

$0.072 * * *$

$(0.022)$

(0.021)

$0.054 * * *$

(0.021)
$0.094 * * *$

(0.016)
Interacted with Log

(0.016)

$\begin{array}{rr}0.004 & 0.00268 \\ (0.014) & (0.014)\end{array}$

Sensitivity

$\begin{array}{lcccccc}\text { Year Effects? } & \mathrm{N} & \mathrm{N} & \mathrm{N} & \mathrm{N} & \mathrm{N} & \mathrm{Y} \\ \text { Industry*Year Effects? } & \mathrm{N} & \mathrm{Y} & \mathrm{Y} & \mathrm{Y} & \mathrm{N} & \mathrm{N} \\ \text { Firm Effects? } & \mathrm{N} & \mathrm{N} & \mathrm{N} & \mathrm{N} & \mathrm{Y} & \mathrm{Y} \\ { } } & 19,325 & 19,325 & 19,325 & 19,325 & 19,325 & 19325 \\ \text { R-Squared } & 0.03 & 0.11 & 0.09 & 0.11 & 0.73 & 0.74 \\ \text { Firms } & 3,247 & 3,247 & 3,247 & 3,247 & 3,247 & 3247\end{array}$

Note: The dependent variable in these regressions is the assumed rate of return on pension assets. Standard errors, reported in parentheses are corrected for firm-level clustering. The sample includes firms in Compustat which report an assumed long-term rate of return on pension plan assets, pension plan asset size, and positive operating income. Financial and pension data are from Compustat; acquisitions data are from the Securities Data Company (SDC) database. *** indicates significance at the $1 \%$ level. 
Dependent Variable: Expected Long-Term Rate of Return on Pension Assets

\begin{tabular}{|c|c|c|c|c|c|}
\hline \multicolumn{2}{|c|}{ equity share controls } & \multicolumn{2}{|c|}{$\begin{array}{c}\text { lagged actual return } \\
\text { controls }\end{array}$} & \multicolumn{2}{|c|}{$\begin{array}{l}\text { CEO option grants / total } \\
\text { compensation controls }\end{array}$} \\
\hline$(1)$ & $(2)$ & (3) & $(4)$ & $(5)$ & $\overline{(6)}$ \\
\hline $\begin{array}{l}0.077 * \\
(0.040)\end{array}$ & $\begin{array}{r}0.009 \\
(0.024)\end{array}$ & $\begin{array}{l}0.080^{* * *} \\
(0.023)\end{array}$ & $\begin{array}{r}-0.004 \\
(0.016)\end{array}$ & $\begin{array}{l}0.120 * * * \\
0.023\end{array}$ & $\begin{array}{l}0.049 * * * \\
0.017\end{array}$ \\
\hline
\end{tabular}

Share of Pension Assets

$0.846 * * * \quad 0.000$

Invested in Equity

$(0.127) \quad(0.077)$

Share of Pension Assets

$0.029 \quad 0.015$

Invested in Equity, Interacted

with Log Sensitivity

(0.076) (0.046)

12-month Actual Pension Return

$2.376 * * * \quad 0.108$

(0.281) (0.162)

12-month Actual Pension

$0.115 \quad 0.049$

Return, Interacted with Log

Sensitivity

(0.118) (0.058)

CEO option grants / total CEO

compensation

$\begin{array}{lr}0.026 \text { *** } & -0.006 \\ (0.008) & (0.006)\end{array}$

CEO option grants / total CEO

compensation

$\begin{array}{rr}0.005 & -0.002 \\ (0.006) & (0.004)\end{array}$

Acquirer Indicator

$0.313 * * * \quad 0.045 * * *$

$0.326 * * *$

$0.046 * * *$

$0.207 * * *$

$0.041 * * *$

(0.028)

(0.014)

(0.029)

$(0.014)$

(0.026)

(0.014)

Acquirer Indicator Interacted

$0.062 * * *$

$0.033 * * *$

$0.069 * * *$

$0.033 * * *$

$0.051 * * *$

$0.030 * * *$

with Log Sensitivity

(0.021)

(0.011)

(0.021)

$(0.011)$

(0.020)

(0.011)

Industry Effects?

Year Effects?

Industry*Year Effects?

Firm Effects?

$\begin{array}{lll}\text { N } & \text { N } & \text { N } \\ \text { N } & \text { Y } & \text { N } \\ \text { Y } & \text { N } & \text { Y } \\ \text { N } & \text { Y } & \text { N }\end{array}$

19,325

0.117

3,247

\begin{abstract}
19,325
\end{abstract}
0.743

3,247
19,325

0.118

3,247

$$
3,247
$$

$\mathrm{N} \quad \mathrm{N}$

$\begin{array}{ll}\mathrm{N} & \mathrm{Y}\end{array}$

$\mathrm{Y} \quad \mathrm{N}$

$\begin{array}{ll}\mathrm{N} & \mathrm{Y}\end{array}$
$\mathrm{N}$

$\mathrm{N}$

N

$\mathrm{N}$

R-Squared

Firms

19,325

0.137

3,247
19,325

0.743

3,247

Note: The dependent variable in these regressions is the assumed rate of return on pension assets. Standard errors, reported in parentheses are corrected for firm-level clustering. The sample includes firms in Compustat which report an assumed long-term rate of return on pension plan assets, pension plan asset size, and positive operating income. Financial and pension data are from Compustat; acquisitions data are from the Securities Data Company (SDC) database; compensation data are from Execucomp. Indicator variables are included for missing control variables, i.e. for missing asset allocation in the first two columns, for missing $12-$ month actual equity returns in the middle two columns, and for missing CEO data for the right two columns. 12-month actual pension returns for 1998-2002 are assumed missing due to incorrect Compustat data for this item during these years. *** and * indicate significance at the $1 \%$ and $10 \%$ levels, respectively. 
Dependent variable: categorical variable for change in long-term rate of return assumption
(1)
(2)
(3)
(4)
(5)
(6)

Log Ratio of Annual Pension

$0.018 * *$

(0.007)
$0.015 *$

(0.008)

$0.019 * * *$

$0.015 *$

(0.007)

Assets to Annual Operating

Income

Log Ratio of Average Pension

Assets to Annual Operating

Income

Log Ratio of Annual Pension

Liabilities to Annual Operating

Income

Acquirer Indicator

$0.067 * * *$

(0.023)

0.015

(0.017)

Acquirer Indicator Interacted

with Log Sensitivity

Acquirer Indicator Marginal Effects

\begin{tabular}{|c|c|c|c|c|c|c|c|c|}
\hline Probability of Decrease & \multicolumn{3}{|c|}{$-1.2 \%$} & - & \multicolumn{3}{|c|}{$-1.2 \%$} & $-1.2 \%$ \\
\hline Probability of No Chg & \multicolumn{3}{|c|}{$0.3 \%$} & - & \multicolumn{3}{|c|}{$0.3 \%$} & $0.3 \%$ \\
\hline Probability of Increase & \multicolumn{3}{|c|}{$0.9 \%$} & - & \multicolumn{3}{|c|}{$1.0 \%$} & $0.9 \%$ \\
\hline \multicolumn{9}{|l|}{ ependent Variable } \\
\hline oarse (3 categories) & $\mathrm{Y}$ & $\mathrm{Y}$ & $\mathrm{N}$ & $\mathrm{N}$ & $\mathrm{Y}$ & $\mathrm{Y}$ & $\mathrm{Y}$ & $\mathrm{Y}$ \\
\hline ne (11 categories) & $\mathrm{N}$ & $\mathrm{N}$ & $\mathrm{Y}$ & $\mathrm{Y}$ & $\mathrm{N}$ & $\mathrm{N}$ & $\mathrm{N}$ & $\mathrm{N}$ \\
\hline bservations & 16,004 & 16,004 & 16,004 & 16,004 & 16,004 & 16,004 & 16,004 & 16,004 \\
\hline
\end{tabular}

Note. The model estimated is an ordered probit. In regressions with coarse dependent variable, the dependent variable takes one of three values: -1 for decrease in rate of return assumption, 0 for no change, and 1 for increase. In regressions with the fine dependent variable, the space of changes in the long-term rate of return assumption is divided into eleven bins. Financial data are from Compustat; acquisitions data are from the Securities Data Company (SDC) database. The sample includes firms in

Compustat which report pension plan asset size, and positive operating income, and assumed long-term rate of return in the current and previous period. Standard errors, reported in parentheses, are corrected for firm-level clustering. ***, **, and * indicate significance at the $1 \%, 5 \%$, and $10 \%$ levels, respectively.

$0.062 * * *$

reported in parenthese, are correted for fimm-level chstering. $* * * *$ and $*$ indicate significance at he $1 \%, 5 \%$, and $10 \%$ levels, respectively. 
Table 10: Assumed long term rates of return, sensitivity measures, and CEO option exercise

Dependent Variable: Assumed Long-Term Rate of Return on Pension Assets

Log Ratio of Annual

Pension Assets to Annual

Operating Income

CEO option exercise as

share of firm equity market

CEO option exercise share

interacted with log

sensitivity

CEO option exercise as

share of options held

CEO option exercise as

share of held, interacted

with log sensitivity

CEO option grants as share

of options held

CEO option grants as share

of held, interacted with log

sensitivity
(1)

(2)

$\begin{array}{lcc}0.154^{* * *} & 0.0588^{* * *} & 0.031 \\ (0.021) & (0.022) & (0.022) \\ & & \\ 0.028 * * * & 0.014 * * * & 0.011 * * * \\ (0.011) & (0.004) & (0.004) \\ 0.013 * * & 0.005 * & 0.005 * \\ (0.006) & (0.003) & (0.003)\end{array}$

(4)

$0.189 * * *$

(5)

(5)

(0.023)

$0.069 * * *$

0.040

(0.027)

\begin{tabular}{lcccccr} 
Industry Effects? & $\mathrm{N}$ & $\mathrm{N}$ & $\mathrm{N}$ & $\mathrm{N}$ & $\mathrm{N}$ & $\mathrm{N}$ \\
Year Effects? & $\mathrm{N}$ & $\mathrm{N}$ & $\mathrm{Y}$ & $\mathrm{N}$ & $\mathrm{N}$ & $\mathrm{Y}$ \\
Industry*Year Effects? & $\mathrm{Y}$ & $\mathrm{N}$ & $\mathrm{N}$ & $\mathrm{Y}$ & $\mathrm{N}$ & $\mathrm{N}$ \\
Firm Effects? & $\mathrm{N}$ & $\mathrm{Y}$ & $\mathrm{Y}$ & $\mathrm{N}$ & $\mathrm{Y}$ & $\mathrm{Y}$ \\
& & & & & & \\
Observations & 7,075 & 7,075 & 7,075 & 5,951 & 5,951 & 5,951 \\
R-Squared & 0.15 & 0.75 & 0.76 & 0.18 & 0.74 & 0.75 \\
Firms & 1,075 & 1,075 & 1,075 & 1,069 & 1,069 & 1069 \\
& & & & & & \\
\hline
\end{tabular}

Note: The dependent variable is the assumed rate of return on pension assets. Data are from Compustat and Compustat Executive Compensation. The sample includes firms in Compustat which report assumed long-term rate of return on pension plan assets, report pension plan asset size, have positive operating income, and have data on executive compensation. Standard errors, reported in parentheses, are corrected for firm-level clustering. ***, **, and * indicate significance at the $1 \%, 5 \%$, and $10 \%$ levels, respectively. 
Dependent Variable: Equity Allocation Share

\begin{tabular}{|c|c|c|c|c|}
\hline \multirow[b]{3}{*}{$\begin{array}{l}\text { Assumed long term rate } \\
\text { of return on pension } \\
\text { assets }\end{array}$} & \multicolumn{2}{|c|}{ Ordinary Least Squares } & \multicolumn{2}{|c|}{ Instrumental Variables } \\
\hline & (1) & $(2)$ & (3) & (4) \\
\hline & $\begin{array}{l}0.060 * * * \\
(0.009)\end{array}$ & $\begin{array}{l}0.045 \text { *** } \\
(0.009)\end{array}$ & $\begin{array}{l}0.280 \text { *** } \\
(0.045)\end{array}$ & $\begin{array}{l}0.202 \text { *** } \\
(0.050)\end{array}$ \\
\hline $\begin{array}{l}\text { Log ratio of annual } \\
\text { pension assets to annual } \\
\text { operating income }\end{array}$ & $\begin{array}{l}0.039 * * * \\
(0.007)\end{array}$ & $\begin{array}{l}0.034 \text { *** } \\
(0.007)\end{array}$ & $\begin{array}{r}0.132 \\
(0.009)\end{array}$ & $\begin{array}{c}0.018 * \\
(0.099)\end{array}$ \\
\hline Industry*Year Effects & $\mathrm{N}$ & $\mathrm{Y}$ & $\mathrm{N}$ & $\mathrm{Y}$ \\
\hline LTROR Instrumented & $\mathrm{N}$ & $\mathrm{N}$ & $\mathrm{Y}$ & $\mathrm{Y}$ \\
\hline Instrument set & & & $\begin{array}{r}\text { Acquis } \\
\text { varial }\end{array}$ & \\
\hline Observations & 3202 & 3202 & 3202 & 3202 \\
\hline
\end{tabular}

Note: This table presents the results of OLS and IV estimation of models for the pension fund's equity allocation share. Asset allocation compiled from Pensions and Investments annual reports and IRS 5500 filings. Firms with assets in opaque trusts are excluded from the sample. The first two columns report the results of linear regressions of equity allocation shares on LTROR and pension sensitivity. The second two columns use a lagged acquirer indicator as an instrumental variable for the long-term rate of return assumption. ${ }^{* * *}$ and $*$ indicate significance at the $1 \%$ and $10 \%$ levels, respectively. 
IBM Performance

IBM Performance

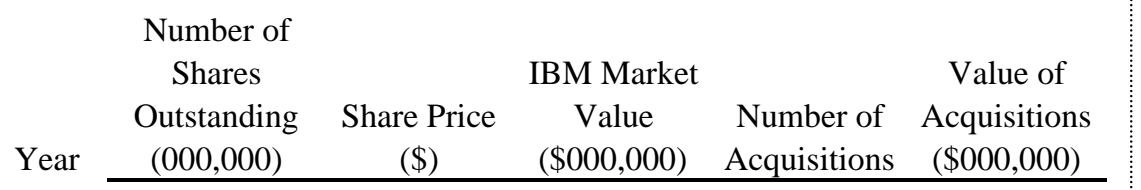

\begin{tabular}{rrrrrrr}
1997 & 958.091 & 104.625 & 100,240 & 4 & 250 \\
1998 & 915.097 & 184.375 & 168,721 & 9 & 828 \\
1999 & $1,784.216$ & 107.875 & 192,472 & 17 & 1,551 \\
2000 & $1,742.900$ & 85.000 & 148,147 & 9 & 511 \\
2001 & $1,723.194$ & 120.960 & 208,438 & 2 & 1,082 \\
\cline { 5 - 6 } \cline { 4 - 6 } & & & Totals & 41 & 4,222 \\
2002 & $1,722.367$ & 77.500 & 133,483 & &
\end{tabular}

IBM Pension Plan Reporting and Impact on IBM Share Price

\begin{tabular}{|ccc}
\multicolumn{3}{c}{ Impact on IBM Share Price } \\
\hline $\begin{array}{c}\text { Share of } \\
\text { Income } \\
\text { Before Taxes } \\
\text { Resulting } \\
\text { from } \\
\text { Deviation } \\
\text { from 9.25\% }\end{array}$ & $\begin{array}{c}\text { Share Price in } \\
\text { Absence of } \\
\text { Deviations } \\
\text { from 9.25\% } \\
(\$)\end{array}$ & $\begin{array}{c}\text { Absence of } \\
\text { Deviations } \\
\text { from 9.25\% } \\
\text { and Lower } \\
\text { Capitalization } \\
(\$)\end{array}$ \\
\hline $1.53 \%$ & 103.029 & 84.441 \\
$1.66 \%$ & 181.312 & 148.601 \\
$1.42 \%$ & 106.341 & 87.156 \\
$4.77 \%$ & 80.942 & 66.339 \\
$4.75 \%$ & 115.210 & 94.424 \\
& &
\end{tabular}

Gerstner Option Activity

\begin{tabular}{|c|c|c|}
\hline $\begin{array}{c}\text { Stock Options } \\
\text { Exercised by } \\
\text { Gerstner (000) }\end{array}$ & $\begin{array}{l}\text { Compensation } \\
\text { Derived from } \\
\text { Deviations from } \\
9.25 \%(\$ 000)\end{array}$ & $\begin{array}{c}\text { Compensation } \\
\text { Derived from } \\
\text { Deviations from } \\
9.25 \% \text { and } \\
\text { Higher } \\
\text { Capitalization } \\
(\$ 000) \\
\end{array}$ \\
\hline 101 & 162 & 2,045 \\
\hline 301 & 923 & 10,782 \\
\hline 803 & 1,232 & 16,641 \\
\hline 703 & 2,854 & 13,122 \\
\hline \multirow[t]{2}{*}{1,253} & 7,206 & 33,253 \\
\hline & 12,377 & 75,843 \\
\hline
\end{tabular}

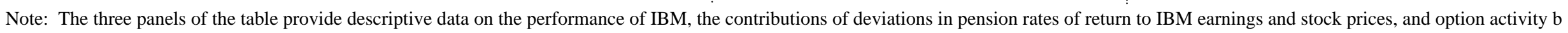

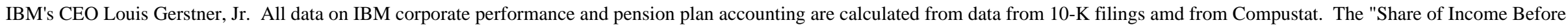

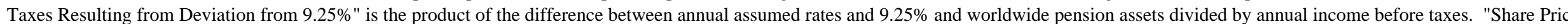

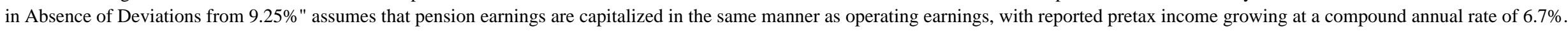

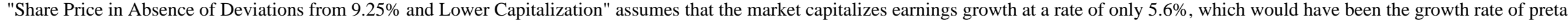

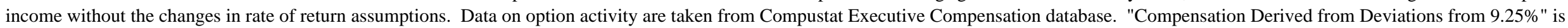
the difference in share prices under the 9.25\% assumption and the actual share price times the number of option exercises. "Compensation Derived from Deviations from 9.25\% and Higher Capitalization" is the difference in share prices under the $9.25 \%$ assumption with lower capitalization and the actual share price times the number of option exercises. 


\begin{tabular}{|c|c|c|c|c|c|c|c|}
\hline $\begin{array}{l}\text { General } \\
\text { Motors } \\
(1992- \\
2002)\end{array}$ & $\begin{array}{c}\text { Verizon } \\
\text { (1991- } \\
\text { 2002) }\end{array}$ & $\begin{array}{c}\text { General } \\
\text { Electric } \\
(1991- \\
2002)\end{array}$ & $\begin{array}{l}\text { Boeing } \\
(1991- \\
2002)\end{array}$ & $\begin{array}{c}\text { Ford } \\
(1992- \\
2002)\end{array}$ & $\begin{array}{l}\text { Lucent } \\
(1994- \\
2002)\end{array}$ & $\begin{array}{c}\text { SBC } \\
(1991- \\
2002)\end{array}$ & $\begin{array}{c}\text { Lockheed } \\
\text { (1992- } \\
\text { 2002) }\end{array}$ \\
\hline
\end{tabular}

2002 DB Pension Plan Assets

(\$bn)

37.6

37.1

31.1

29.0

28.2

24.9

17.9

Median Sensitivity

6.47

7.67

4.92

Mean Sensitivity

4.00

2.75

6.09

1.57

11.93

2.24

6.77

Rate of Return

$9.95 \%$

$8.67 \%$

$9.42 \%$

$8.63 \%$

$9.16 \%$

$9.00 \%$

$8.44 \%$

$8.98 \%$

$9.18 \%$

Standard Deviation of

Assumed LTROR

$\begin{array}{rr}0.10 \% & 0.54 \% \\ 9.70 \% & 7.50 \% \\ 10.00 \% & 9.25 \%\end{array}$

$0.29 \%$
$8.50 \%$
$9.50 \%$

$0.43 \%$
$8.00 \%$
$9.25 \%$
7
4
3

$0.28 \%$
$8.75 \%$
$9.50 \%$

$0.00 \%$
$9.00 \%$
$9.00 \%$

$0.57 \%$

\section{$0.67 \%$}

$0.25 \%$

Maximum

2
2

1
-
1

$\begin{array}{ll}3 & - \\ 1 & - \\ 2 & -\end{array}$

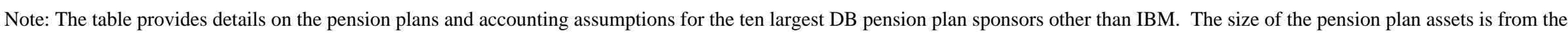

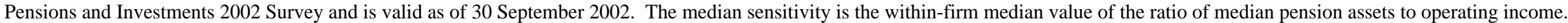

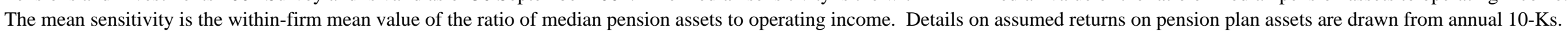

